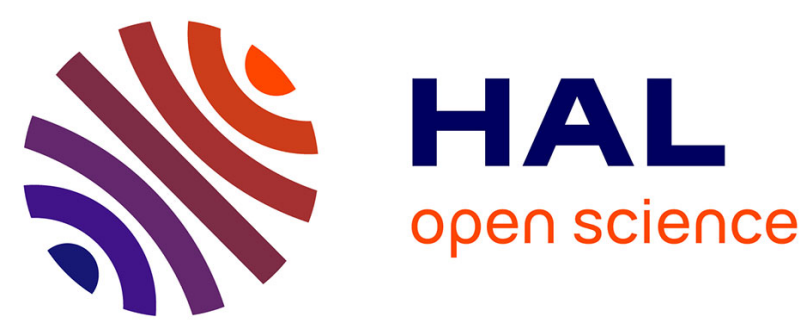

\title{
Trophic ecology of the juveniles of two jack species (Caranx latus and C. hippos) in contrasted tropical estuaries
}

Julio Guazzelli Gonzalez, Audrey M. Darnaude, Paulo J. Duarte-Neto, Francois Le Loc'H, Mayara Constantino De Lima, Frédéric Ménard, Valdimere Ferreira, Flavia Lucena Fredou, Jean-Marie Munaron, Thierry Fredou

\section{To cite this version:}

Julio Guazzelli Gonzalez, Audrey M. Darnaude, Paulo J. Duarte-Neto, Francois Le Loc'H, Mayara Constantino De Lima, et al.. Trophic ecology of the juveniles of two jack species (Caranx latus and C. hippos) in contrasted tropical estuaries. Estuarine, Coastal and Shelf Science, 2021, 255, pp.107370. 10.1016/j.ecss.2021.107370 . hal-03413531

\section{HAL Id: hal-03413531 \\ https://hal.umontpellier.fr/hal-03413531}

Submitted on 10 Nov 2021

HAL is a multi-disciplinary open access archive for the deposit and dissemination of scientific research documents, whether they are published or not. The documents may come from teaching and research institutions in France or abroad, or from public or private research centers.
L'archive ouverte pluridisciplinaire HAL, est destinée au dépôt et à la diffusion de documents scientifiques de niveau recherche, publiés ou non, émanant des établissements d'enseignement et de recherche français ou étrangers, des laboratoires publics ou privés. 


\section{Journal Pre-proof}

Trophic ecology of the juveniles of two jack species (Caranx latus and C. hippos) in contrasted tropical estuaries

Júlio Guazzelli Gonzalez, Audrey M. Darnaude, Paulo J. Duarte-Neto, François Le Loc'h, Mayara Constantino de Lima, Frédéric Ménard, Valdimere Ferreira, Flávia Lucena Frédou, Jean-Marie Munaron, Thierry Frédou

PII: S0272-7714(21)00223-7

DOI: https://doi.org/10.1016/j.ecss.2021.107370

Reference: $\quad$ YECSS 107370

To appear in: Estuarine, Coastal and Shelf Science

Received Date: 13 October 2020

Revised Date: 13 March 2021

Accepted Date: 7 April 2021

Please cite this article as: Gonzalez, Jú.Guazzelli., Darnaude, A.M., Duarte-Neto, P.J., Le Loc'h, Franç., Lima, M.C.d., Ménard, Fréé., Ferreira, V., Frédou, Flá.Lucena., Munaron, J.-M., Frédou, T., Trophic ecology of the juveniles of two jack species (Caranx latus and C. hippos) in contrasted tropical estuaries, Estuarine, Coastal and Shelf Science (2021), doi: https://doi.org/10.1016/j.ecss.2021.107370.

This is a PDF file of an article that has undergone enhancements after acceptance, such as the addition of a cover page and metadata, and formatting for readability, but it is not yet the definitive version of record. This version will undergo additional copyediting, typesetting and review before it is published in its final form, but we are providing this version to give early visibility of the article. Please note that, during the production process, errors may be discovered which could affect the content, and all legal disclaimers that apply to the journal pertain.

(c) 2021 Published by Elsevier Ltd. 
1 Trophic ecology of the juveniles of two jack species (Caranx latus and C. hippos) in contrasted tropical 2 estuaries.

3

4 Júlio Guazzelli Gonzalez ${ }^{\mathrm{a}, \mathrm{b},{ }^{*}}$, Audrey M. Darnaude ${ }^{\mathrm{b}}$, Paulo J. Duarte-Neto ${ }^{\mathrm{c}}$, François Le Loc'h ${ }^{\mathrm{d}}$, Mayara 5 Constantino de Lima ${ }^{a}$, Frédéric Ménard ${ }^{e}$, Valdimere Ferreira ${ }^{a}$, Flávia Lucena Frédou ${ }^{a}$, Jean-Marie 6 Munaron $^{\mathrm{c}}$, Thierry Frédou ${ }^{\mathrm{a}}$

7 anniversidade Federal Rural de Pernambuco, UFRPE, Departamento de Recursos Pesqueiros e 8 Aquicultura, Rua Dom Manuel de Medeiros, s/n, Recife, PE. CEP: 52.171-900, Brazil.

$9 \quad{ }^{b}$ MARBEC, Univ. Montpellier, CNRS, IRD, Ifremer, Montpellier, France.

10 'Universidade Federal Rural de Pernambuco, UFRPE, Departamento de Estatística e Informática, Rua 11 Dom Manuel de Medeiros, s/n, Recife, PE. CEP: 52.171-900, Brazil

12 dIRD, Univ Brest, CNRS, Ifremer, LEMAR, F-29280 Plouzane, France

13 eAix Marseille Univ, Univ Toulon, CNRS, IRD, MIO, UM110, Marseille, France.

$14 \quad$ *Corresponding author: julio.guazzelli-gonzalez@etu.umontpellier.fr Tel (+55 81) 3320-6605 


\section{Abstract}

Jacks are highly prized tropical marine fish. Most of them complete their whole life cycle at sea but some use estuaries at the juvenile stage before moving back to coastal waters and joining the adult exploited stocks. Little is known about jacks' trophic ecology in estuaries, although their juveniles' ability to successfully exploit available resources in these productive environments may strongly affect stock recruitment success in the species concerned. In this study, stomach content and stable isotope analyses were combined to investigate diet and food niche overlap of juveniles from two sympatric species of jacks (Caranx latus and C. hippos) in three contrasted estuaries (Suape, Sirinhaém and Santa Cruz) spread along the northeastern Brazilian coast. Overall, although the juveniles of C. latus exhibited a more piscivorous diet than those of $C$. hippos, the two species had very similar isotopic niches, with mean $\delta^{13} \mathrm{C}$ and $\delta^{15} \mathrm{~N}$ values of $-19.35 \pm 2.10 \%$ and $11.03 \pm 1.11 \%$ and of $-19.10 \pm 1.82 \%$ and $10.21 \pm 1.21 \%$, for $C$. hippos and C. latus respectively. In all the estuaries sampled, both species mostly ate fish $\left(N_{\mathrm{i}}=20.1\right.$ $46.2 \%, W_{\mathrm{i}}=60.1-75.1 \%$, essentially Gobiidae and Clupeidae $)$ and crustaceans $\left(N_{\mathrm{i}}=26.0-65.9 \%, W_{\mathrm{i}}=\right.$ $23.3-38.2 \%$, mainly Penaeidae shrimps). As a result, the overlap between their global estuarine isotopic niches was $>68 \%$. However, diet composition for the two species varied among estuaries, indicating that their juveniles partly adapt their food preferences to local prey availability. Notably, prey preferences differed significantly between the two species only in the Santa Cruz estuary, where $\delta^{15} \mathrm{~N}$ values were the highest for both species. Conversely, interspecific differences in $\delta^{13} \mathrm{C}$ ratios were greater in the Suape and the Sirinhaém estuaries, likely reflecting a wider diversity in the carbon sources sustaining local food webs. Thus, combined differences in juvenile diet and food web structure at each location resulted in much-reduced local isotopic niche overlaps between the two species (from $27 \%$ in Suape to $57 \%$ in Santa Cruz). These results have important implications for resource and ecosystem management in northeastern Brazil and call for systematic cross-site comparisons when evaluating fish ecology and resource partitioning within estuarine systems.

Keywords: Marine fish, Trophic relationships, Stomach content, Stable isotope analysis, Carbon, Nitrogen. 


\section{Introduction}

44

45

46

47

48

49

50

Estuaries are highly exploited ecosystems a host a high number of fish species (Blaber 1997; Vasconcelos et al., 2015), many of which colonize them during the juvenile stage seeking for protection and favorable growth conditions (Nagelkerken et al., 2000; Beck et al., 2001; Dahlgren et al., 2006). Although knowledge on the use of estuaries by tropical fishes has significantly grown in recent years (Blaber, 2013), the information available concerns only a few estuarine systems so further research is needed to assess the actual value of tropical estuaries as fish juvenile habitats (Blaber and Barletta, 2016). Indeed, a variety of biological and physical factors might affect the physiology of fish and their resource use in estuaries (Blaber, 2007). For instance, estuaries' morphology and spatiotemporal dynamics modulate not only fish diversity (França et al., 2012; Vasconcelos et al., 2015), but also food web structure and composition (Harrison and Whitfield, 2006, 2012; Silva-Júnior et al., 2017), resource availability (Doi et al., 2009; Hoeinghaus et al., 2011; Boucek and Rehage, 2013) and seascape connectivity (Sheaves, 2009; Ogden et al., 2014). The degree to which each species benefits from available food resources in these complex environments may also influence the survival and fitness of fish juveniles (Le Pape and Bonhommeau, 2015; Yeung and Yang, 2017; Hiraoka et al., 2019). Therefore, investigating species' resource use in contrasted estuarine juvenile habitats can not only improve the knowledge and understanding of their ecology (e.g. Stevens et al., 2018) but also help defining local management strategies (Sheaves et al., 2015). This is particularly true in tropical regions where the socioeconomic demand for coastal fish resources is growing (Barlow et al., 2018; FAO, 2018) and where environmental awareness is only just emerging (Mitra and Zaman, 2016).

Species ecological niches play a central role in defining available resource use and interspecific interactions at the community level (Van Valen, 1965; Ross, 1986). Among the many facets of the ecological niche, the trophic niche is perhaps the easiest to evaluate (Ross, 1986). It can be studied using empirical methods like stomach content analysis (SCA), which provides a snapshot of the items ingested by the individuals (Hyslop, 1980; Pinnegar and Polunin, 2000), or through the use of natural tags such as stable isotope analysis (SIA). This later approach, usually combines nitrogen $\left(\delta^{15} \mathrm{~N}\right)$ and carbon $\left(\delta^{13} \mathrm{C}\right)$ isotopic ratios (Fry, 2006) to provide an integrated image of the food resources assimilated by the individuals over periods of time ranging from a few weeks to a few months (Herzka, 2005). The method relies on the assumption that the isotope ratios of an organism reflect, in a predictive way, those of its food sources (Fry, 2006). In general, the $\delta^{15} \mathrm{~N}$ is used as a proxy for organisms' trophic position in the 
food chain (Post, 2002; Martínez Del Rio et al., 2009), while the $\delta^{13} \mathrm{C}$ allows identifying the main organic matter source(s) supporting their growth (Fry, 2006; Layman, 2007). Combining SIA and SCA enables better resolution of dietary patterns and accurate identification of the food sources sustaining animal growth (Silveira et al., 2020). In this study, we applied these complementary methods to describe variations in diet and compare strategies of estuary resource use in the juveniles of two sympatric species of jacks along the northeastern coast of Brazil.

Jacks (Caranx spp.) are marine fish found both in inshore and offshore coastal environments (Figueiredo and Menezes, 1980; Smith-Vaniz, 2002). Although these large predators are neritic and reef associated when adult, some of them may use a mosaic of habitats along their life cycle and colonize inshore estuaries as juveniles (Smith-Vaniz, 2002). This is the case for both the horse-eye jack (Caranx latus, Agassiz 1831) and the crevalle jack (Caranx hippos, Linnaeus 1766), two highly exploited species with a widespread distribution in the Atlantic Ocean (Figueiredo and Menezes, 1980). In Brazil, C. latus and C. hippos represent almost $75 \%$ of the national landings for jacks, with more than 6.000 tons fished annually between 2009 and 2011 (MPA, 2011). Yet, little is known about their life cycle and their ecology at the juvenile stage. The yearlings of the two species are found in a broad range of inshore and coastal habitats along the Brazilian coast (Figueiredo and Menezes, 1980; Paiva and Araújo, 2010), and information regarding their trophic ecology in estuaries is particularly scarce (e.g. Vasconcelos Filho et al., 2010; Medeiros et al., 2017).

Differences in resource use among juvenile habitats may affect fish early growth and body condition (e.g. Isnard et al. 2015) and modulate recruitment success in exploited species (Gillanders et al., 2015). To avoid competition for food and optimize energy acquisition, sympatric species usually tend to partition resources at multiple scales (Schoener, 1974; Losos, 2000). However, C. latus and C. hippos not only have similar body shapes and lengths, but they are also both reported to feed mainly on fish and crustaceans (Hofling et al., 1998; Smith-Vaniz, 2002; Vasconcelos Filho et al., 2010). Therefore, they might have similar uses of estuarine resources and their co-occurrence in certain estuaries might result in an interspecific competition for food, with potentially high consequences in terms of local fisheries production. To investigate this, we assessed variations in the diets and isotopic niches of their juveniles among three neighboring Brazilian estuaries with contrasted morphological and biological features, and where the relative densities for the juveniles of the two species differ markedly (Paiva and Araújo, 2010; 
102

103

104

105

106

107

108

109

110

111

112

113

114

115

116

117

118

119

120

121

122

123

124

125

126

127

128

129

130

131

Silva-Júnior et al., 2017), which allowed exploring whether their feeding strategies change under different degrees of potential competition.

\section{Material and Methods}

\subsection{Study area}

The three tropical estuarine systems selected for this work (Santa Cruz, Suape and Sirinhaém, Fig. 1) are located in the western South Atlantic Ocean, along the coast of the Pernambuco state, on the northeastern coast of Brazil. In this area, the climate is sub-tropical, with annual temperatures ranging from 18 to $32^{\circ} \mathrm{C}$, around an annual mean of $24^{\circ} \mathrm{C}(\mathrm{CPRH}, 2003$; 2003a). Rainfalls occur all year round along the shore but they are more intense in the late autumn and winter (May to August). The driest period of the year is late spring and early summer (from October to December) due to the northward displacement of the Intertropical Convergence Zone (ICTZ) in the Atlantic and the occurrence of stronger southeast trade winds (CPRH, 2003; 2003a; Hounsou-gbo, et al. 2015). The local climate is influenced both by seasonal (displacement of the ICTZ) and by inter-annual (e.g. El Niño Southern Oscillation ENSO) meteorological phenomena, which results in a highly variable weather and precipitation patterns among years (Hastenrath, 2012).

Although relatively close to each other, the Santa Cruz, Suape and Sirinhaém estuaries exhibit distinct morphological and biological features and are subject to different freshwater inputs and degrees of anthropogenic pressures (Table 1). Located in the north of the Pernambuco state, the estuarine complex of Santa Cruz is the largest estuary of the three, and one of the most important fishery ground of the state (Medeiros et al., 2001). It consists in a shallow U-shape channel that receives continental inputs from six rivers (draining three hydrological basins) and is connected to the sea by two large entrances (Silva et al., 2011). Because the seawater inflow is high, the estuary is under a strong marine influence (Flores Montes et al., 1998; Figueiredo et al., 2006). Furthermore, the reduced current velocity in the inner part of the main channel results in a predominance of muddy substrates along the estuary (CPRH, 2003), where hypersaline conditions prevail during the driest months of the year (Medeiros and Kjerfve, 1993). The local fauna comprises a large number of marine and estuarine invertebrates and fish that use this estuary at different stages of their life (Vasconcelos-Filho and Oliveira, 1999). The fish assemblage is diverse, with numerous species with distinct morphologies, as illustrated by the presence of bottom-associated species like gobies (Silva-Júnior et al., 2017; Ferreira et al., 2019). 

smaller (Table 1). Because the annual rainfall in the state increases southwards (CPRH, 2003a), they receive higher freshwater inputs, especially Sirinhaém (Table 1). The Suape estuary is formed by two rivers, which flow into a shallow brackish lagoon with limited connection to the sea. It can be classified as euryhaline and exhibits the lowest primary productivity of the three estuaries studied (Silva et al., 2019; Table 1). The estuary of Sirinhaém is the smallest estuary studied, but that with the highest percentage of mangrove cover (Table 1). Located within two marine protected areas (CPRH, 2003a), it gathers a variety of interconnected lagoons and channels that spread on the shallow flood plain around the main bed of the Sirinhaém river, which constitutes its sole connection to the sea (CPRH, 2003a). This particular configuration intensifies the effects of the watershed dynamics, with salinities ranging from nearly 0 at low tide to up to 30 at high tide (Silva et al., 2009). The fish assemblages of the Sirinhaém and Suape estuaries are similar, with a common dominance of pelagic species (Bezerra Junior et al., 2011). Moreover, both estuaries exhibit much lower densities of C. hippos than those observed in Santa-Cruz (Silva-Júnior et al., 2017).

\subsection{Fish sampling and diet composition}

The Caranx latus and C. hippos juveniles used for this work were captured over five successive years (2015-2019), using both beach seines (20 x $1.9 \mathrm{~m}$, mesh $20 \mathrm{~mm})$, trawled along the river banks, and block nets ( $350 \times 2.9 \mathrm{~m}$, mesh $70 \mathrm{~mm})$ set close to mangrove creeks. Although sampling design was not even among years and estuaries, sampling surveys in each estuary were carried out for all months and always included the same locations (Fig. 1). To account for potential changes in feeding habitat preferences according to the season or increasing fish size, juvenile jacks were systematically sampled in all the main types of habitat they occupy in each estuary. These habitat types were determined according to local fishermen's knowledge on Caranx sp. occurrence in the estuaries and confirmed by prior exploratory surveys. They comprise main foraging grounds for the two species, within and outside the shore-fringed mangroves that predominate in the three estuaries. In all three estuaries, both the mudbanks below fringing mangrove and the adjacent river banks, of maximum $1.5 \mathrm{~m}$ depth, were sampled at low tide. However, in the larger and deeper Santa Cruz estuary, juvenile jacks were also systematically collected within the central channel of the estuary, where water depth remains above $5 \mathrm{~m}$ at low tide. On the river banks and in the Santa Cruz central channel, sediments are composed of a mix of thin sand and 
162

163

164

165

166

167

168

169

170

171

172

173

174

175

176

177

178

179

180

181

182

183

184

185

186

187

188

189

190

silt, and mangrove litter and macroalgae occasionally found on the bottom. Depending on the size and geomorphology of the estuary, fish juveniles were collected at 2 to 5 sites per habitat type for each sampling date. This allowed covering most of the spatiotemporal variability in juvenile distribution, and associated diet variation, between and within estuaries for the two species.

Upon collection, all juveniles were identified following specific literature (Figueiredo and Menezes, 1980; Smith-Vaniz, 2002), measured (standard length - SL in mm) and stored frozen until further analysis. Their stomach contents were assessed under a stereomicroscope until 70 non-empty stomachs per species and estuary could be gathered. As densities for the two jack species are rather low in estuaries during the wetter months of the year (Vilar et al., 2011; Silva-Júnior et al., 2017; da Silva et al., 2018), fish from different years had to be pooled to reach a minimum number of 10 non-empty stomachs for both the dry (September to March) and the rainy (April to August) seasons in the area (CPRH, 2003; 2003a), and a maximum of 30 individuals per year for each estuary. Prey items in all stomachs were identified to the lowest taxonomic level possible, depending on their degree of digestion. All identified prey items were counted and weighed (g) and well-preserved ones, i.e. those only slightly digested, were measured (total length, in $\mathrm{mm}$ ).

For both species, global diet composition was characterized using the frequency of occurrence $\left(F_{\mathrm{i}}\right)$ and the relative percentage in number $\left(N_{\mathrm{i}}\right)$ and in weight $\left(W_{\mathrm{i}}\right)$ of each prey item. $F_{\mathrm{i}}$ corresponds to the number of individual stomachs containing the prey item $i$ divided by the total number of stomachs containing food. $N_{\mathrm{i}}$ and $W_{\mathrm{i}}$ represent the relative number or weight of the prey item $i$ divided by the total number or total weight of prey in the stomachs, respectively. In order to account for the uncertainty associated to these indexes and provide a confidence interval (95\%) for each prey item, a bootstrap procedure based on 5000 re-sampling trials was used (Tirasin and Jorgensen, 1999). The importance of each prey item in the diet was estimated using the alimentary coefficient $(Q)$ proposed by Hureau (1970):

$$
Q=N_{\mathrm{i}} \times W_{\mathrm{i}} .
$$

According to Hureau (1970), prey items should be considered preferential when $Q \geq 200$, secondary when $20 \leq Q<200$, and occasional $(Q<20)$. All dietary indexes were calculated both using major taxonomic groups (e.g. Teleostei) and applying the lowest possible identification levels, down to family.

\subsection{Stable isotope analyses (SIA)}



for both species in our samples was $35 \mathrm{~mm}$ SL, these fish were chosen to measure at least $60 \mathrm{~mm}$ in size

193 (SL) to ensure that the isotopic compositions from their local prey were incorporated within the tissue at the time of capture (Herzka 2005). Fish were collected in 2015, 2018 and 2019 during both the dry and the rainy seasons (APAC, 2019), so their isotopic ratios should accurately reflect the temporal (inter and intra-annual) variabilities in fish diet and food web composition at each estuary. Basal estuarine organic matter sources, i.e. the main benthic algae (Sargassum spp., Ulva spp., Gracilaria cervicornis), the microphytobenthos, the mangrove trees (rotten leaves from Rhizophorae mangle), and the organic matter present in the surface sediment (SOM) and in the water column (POM), were collected in each estuary in 2015, both during the dry (January to March) and the rainy (July to September) seasons (APAC, 2019). Mangrove tree leaves and algae were collected manually at low tide. POM was obtained by filtering water $(0.5-1 \mathrm{~L})$ on precombusted fiberglass filters $(0.75 \mu \mathrm{m})$, whereas SOM was sampled from the $2 \mathrm{~mm}$ surface layer of the sediment. Benthic microphytobenthos was collected from the sediment surface at low tide and extracted in the laboratory following Riera and Richard (1996). Other potential organic matter sources for the three estuaries studied, such as marine POM and SOM from the adjacent coastal zone were also collected, at two locations: one near the entrance of the Santa Cruz estuary and one further south, near the mouths of the Sirinhaém and Suape estuaries.

For fish specimens, white muscle was extracted and rinsed with distilled water while, for organic matter sources, samples were analyzed whole. Samples were dried in an oven at $60^{\circ} \mathrm{C}$ for 48 hours and ground into a fine powder with a mortar and pestle. For all POM and SOM samples, a subsample was acidified to remove the inorganic carbon prior $\delta^{13} \mathrm{C}$ analysis, while the remaining material was used directly for $\delta^{15} \mathrm{~N}$ analyses (Pinnegar and Polunin, 1999). Carbon and nitrogen isotope ratios were analyzed with a mass spectrometer (Thermo Delta $\mathrm{V}+$ ) coupled to an element analyzer (Thermo Flash 2000, interface Thermo ConFio IV) at the Pôle de Spectrométrie Océan (PSO - IUEM, Plouzané, France). Carbon and nitrogen isotopic ratios are reported as $\delta^{13} \mathrm{C}$ and $\delta^{15} \mathrm{~N}$ values (in \%o), respectively, derived from the formula:

$$
\delta \mathrm{X}=\left[\left(R_{\text {sample }} / R_{\text {standard }}\right)-1\right] \times 10^{3}
$$
standard, for carbon or nitrogen, respectively. The standards used for $\delta^{13} \mathrm{C}$ and $\delta^{15} \mathrm{~N}$ were the Pee Dee 
221

222

223

224

225

226

227

228

229

230

231

232

233

234

235

236

237

238

239

241

242

243

244

245

246

247

248

249

analyses, monitored through the repeated analysis (every six samples) of an internal standard (Thermo Acétanilide), was of $0.10 \%$ and $0.07 \%$ for carbon and nitrogen isotopes, respectively.

\subsection{Data analysis}

All statistical analyses were made with the R software (R Core Team, 2019), using the packages vegan (Oksanen et al., 2017), boot (Canty and Ripley, 2020) and SIBER ("Stable Isotope Bayesian Ellipses in R" (Jackson and Parnell, 2016)). Only the prey items observed more than once within the stomachs analyzed were kept for SCA data analyses.

Because body size modulates the type and size of the prey consumed by an organism (Shelton et al., 1977), potential differences in the size (SL in $\mathrm{mm}$ ) of the fish used for SCA were investigated, among estuaries and between species. Kruskal-Wallis tests were used for this, as the assumptions of data normality and homoscedasticity were not met. Then, the relationship between fish size and prey length was assessed for each species using covariance analyses (ANCOVA). Differences in prey length according to the species and the sampling location were also tested, using Kruskal-Wallis tests as data did not meet the assumptions of normality and homoscedasticity. Lastly, differences in diet composition according to fish size were evaluated for both $C$. latus and C. hippos, using two non-parametric permutational multivariate analyses of variance (PERMANOVA), one per species. The PERMANOVA procedure performs a sequential test of terms based on distance matrices and allows for hypotheses testing between predictor variables (Anderson, 2001).

PERMANOVA tests were also applied to investigate differences in diet composition between species (C. latus/ C. hippos), among estuaries (Santa Cruz/ Suape/ Sirinhaém) and between the two species in each estuary. Post-hoc comparisons were applied only for variables with a significant effect on the diet $(p<0.05)$. The distance matrices were based on Bray-Curtis dissimilarity computed from $\log (x+1)$ transformed data of prey relative weight for each individual fish. In addition, two dietary matrixes were used separately to assess the effect of prey identification on the analyses: one including all prey items and the other with only the prey items identified at least to the order level.

Potential differences in the size (SL in $\mathrm{mm}$ ) of the juveniles used for SIA and in their isotopic ratios (both for carbon and for nitrogen, separately) were tested between locations and fish species using separate ANOVA models. Post-hoc Tukey's tests were applied on variables with significant effects in the 
250

251

252

253

254

255

256

257

258

259

260

261

262

263

264

265

266

267

268

269

270

271

272

273

274

275

276

277

278

279

isotopic composition of jacks $(p<0.05)$. The trophic positions of the juveniles of the two jack species were compared by evaluating the areas occupied by their isotopic niches, computed using the corrected standard ellipses area $\left(\mathrm{SEA}_{\mathrm{C}}\right)$ method, which measures the space occupied by a species in a bidimensional plane, here $\delta^{13} \mathrm{C} v s . \delta^{15} \mathrm{~N}$ (Jackson et al., 2011). This approach is less sensitive to variations in sample size than other conventional metrics (Jackson et al., 2011; Syväranta et al., 2013), and provides insightful information on predators' resource use by incorporating both the variance in the isotopic ratios of local basal food sources and the difference in the energy pathways that their prey rely on (Bearhop et al., 2004). Indeed, although a considerable part of the variation in predator isotopic niches can be attributed to diet, it may also reflect differences in prey isotope ratios and in the organic matter sources sustaining food webs (Newsome et al., 2007; Flaherty and Ben-David, 2010). Therefore, the percentage of overlap between the isotopic niches $\left(\mathrm{SEA}_{\mathrm{C}}\right)$ of the two species was used to measure the degree to which they may rely on similar food resources. In order to account for the uncertainty associated to $\mathrm{SEA}_{\mathrm{C}}$ overlaps, a Bayesian approach was applied to assess the mean and $95 \%$ credible intervals $\left(\mathrm{CI}_{95 \%}\right)$ of isotopic niche overlaps between the two species (Jackson et al., 2011).

\section{Results}

Although the total sample of juvenile jacks gathered over the five years of survey was more than satisfactory $(n=439$ of $\mathrm{SL}=35-157 \mathrm{~mm})$, the numbers and the sizes of the juveniles varied between species and estuaries. For example, while total abundances were comparable at all locations for C. latus, C. hippos juveniles were 2- to 3-fold less common in Sirinhaém and Suape (Fig. 2). As a result, the total number of juveniles collected was higher for C. latus $(\mathrm{n}=266)$ than for C. hippos $(\mathrm{n}=173)$. In turn, although the juveniles of $C$. latus $(\mathrm{SL}=105 \pm 25 \mathrm{~mm})$ were consistently bigger $(p<0.001)$ than those of C. hippos ( $\mathrm{SL}=88 \pm 26 \mathrm{~mm}$ ), patterns of size variation between estuaries were similar for the two species, with consistently bigger juveniles $(p<0.001)$ in Suape and smaller ones $(p<0.001)$ in Sirinhaém (Fig. 2). These differences were considered during fish sub-sampling for both stomach content analysis and SIA, in order to reduce bias in our conclusions and provide a realistic overview of the global trophic ecology of the two species.

Among the 394 fish selected for stomach content analysis, few had empty stomachs ( $33 \%$ for $C$. latus and $6 \%$ for $C$. hippos). Relative numbers and size distributions in the 338 remaining ones (207 C. latus and 131 C. hippos) were similar to those observed in the total catches, with slightly higher mean SL 
values for C. latus than for C. hippos in every estuary, and larger juvenile sizes in Suape for both species

281

282

283

284

285

286

287

288

289

290

291

292

293

294

295

296

297

298

299

300

301

302

303

304

305

306

307

308

309

(Table 2). Muscle samples from 112 juvenile fish (60 C. latus and 52 C. hippos) were analyzed in SIA

(Table 2). To allow for muscle signature to reflect the diet in the estuaries, the minimum size of the fish selected for the SIA was $65 \mathrm{~mm}$ (SL). Altogether, the distribution of SIA juvenile sizes was similar for the two species $(p=0.905)$, however it varied between estuaries $(p<0.001)$, reflecting the differences in sizes observed in the field. As for SCA, this sub-sample contained a larger number of individuals from Santa Cruz in order to reflect the higher abundance of juvenile jacks at this estuary.

\subsection{Diet composition}

Overall, diet composition was not significantly different between the two jack species $(p=0.089)$ which both mainly ate fish and crustaceans (Q $>1205$, Table 3). All other prey items were found to be occasional $(Q<20)$, irrespective of the species (Table 3). However, when considering only the prey items identified to at least the order level, the two species did show significant differences in diet composition $(p=0.010)$. Although fish remains in the stomachs were often too digested to be identified, fish prey belonged to at least nine different families for C. latus; six for C. hippos (Table 3). Fish (Teleostei) were the main prey of the juveniles of $C$. latus $(Q=3252)$, whereas $C$. hippos fed on fish $(Q=1205)$ and crustaceans $(Q=2537)$ in similar proportions (Table 3). Fish dominated the diet of both species in terms of occurrence and weight, but crustaceans prevailed in number in the diet of C. hippos (Table 3). For both species, most of the fish prey identified were Gobiidae $\left(F_{\mathrm{i}}=19.0\right.$ to $23.6 ; N_{\mathrm{i}}=4.3$ to $7.5 ; W_{\mathrm{i}}=33.2$ to $39.9 \%)$, but their consumption was higher in C. latus $\left(F_{\mathrm{i}}=23.6 ; N_{\mathrm{i}}=7.5 ; W_{\mathrm{i}}=39.9 \%\right)$. Decapods, in particular Penaeidae shrimps, were the main crustacean prey found in the stomachs of the juveniles of the two species (Table 3). However, mysids also contributed significantly to their diet, especially for $C$. hippos, in which they were the most abundant crustacean prey $\left(N_{\mathrm{i}}=36.6 \%\right)$.

Overall diet composition was found to be similar across the full size-range of the juveniles studied irrespective of the species (C. latus: $p=0.089$; C. hippos: $p=0.193)$ and, when considering only the prey items identified to at least the order level, significant differences in diet according to fish size were found solely for $C$. latus $(p=0.034)$. Even then, only a slightly higher contribution in weight of fish prey was observed in C. latus juveniles larger than $60 \mathrm{~mm}$ (SL). The standard length of the juveniles did not have any significant effect on the sizes of their two main prey, namely fish (adjusted $r^{2}=0.01, p=0.591$ ) and shrimps (adjusted $r^{2}<0.01, p=0.376$ ). The size of these later were similar in all estuaries (Fish, $p=$ 
310

311

312

313

314

315

316

317

318

319

320

321

322

323

324

325

326

327

328

329

330

331

332

333

334

335

336

337

338

339

0.292; Shrimps, $p=0.839$ ) and for both jack species (Fish, $p=0.184$; Shrimps, $p=0.515$ ) (Supplementary Fig. S1).

The diet of both species varied according to the estuary, regardless the level of prey identification applied $(p<0.002)$. Specifically, differences between estuaries were found only for Suape (Suape - Santa Cruz: $p<0.015$; Suape - Sirinhaém: $p<0.027$ ). In this estuary, $C$. hippos presented the most different diet, composed mainly of fish prey $\left(F_{\mathrm{i}}=60.0 ; N_{\mathrm{i}}=33.8 ; W_{\mathrm{i}}=81.4 \%\right)$. The diets of the two species were similar between Santa Cruz and Sirinhaém, either when considering all prey items $(p=0.060)$ or only those identified to at lowest taxonomic level $(p=0.204)$. Moreover, interspecific differences in diet composition were only significant in Santa Cruz, independently of the level of prey identification applied $(p<0.025)$. In this estuary, Gobiidae fish prevailed in the diet of C. latus and decapod shrimps in that of C. hippos (Supplementary Table S1). Although the two species had similar overall diets in the two remaining estuaries (Suape: $p>0.236$; Sirinhaém: $p>0.113$ ), they presented slight spatial variations in their prey preferences. In Suape, the diet of the two species only differed in terms of the type of fish consumed, with higher contributions of Clupeidae and Engraulidae for C. hippos, and of Gobiidae and Gerreidae for C. latus (Supplementary Table S2) while, in Sirinhaém, significantly higher proportions of crustaceans (Penaeidae shrimps) were found in the diet of C. hippos than in that of C. latus (Supplementary Table S3).

\subsection{Stable isotopes analysis}

The juveniles from the two species had very variable $\delta^{13} \mathrm{C}$ and $\delta^{15} \mathrm{~N}$ values irrespective of their estuary of capture, ranging from -24.36 to $-15.73 \%$ and from 8.00 to $13.66 \%$, respectively (Table 2; Fig. 3). Due to this variability, $\delta^{13} \mathrm{C}$ values were not significantly different among estuaries $(p=0.088)$ nor between species, with average values of $-19.10 \pm 1.82 \%$ for C. latus and $-19.35 \pm 2.10 \%$ for C. hippos. Differences in $\delta^{13} \mathrm{C}$ values between the two species were not significant either within each given estuary $(p=0.147)$. Conversely, significant differences in $\delta^{15} \mathrm{~N}$ were found according to both the estuary $(p<$ $0.001)$ and the species $(p<0.001)$. Indeed, although $\delta^{15} \mathrm{~N}$ values for both species did not differ significantly between Suape and Sirinhaém ( $p=0.790$; Fig. 3), they were consistently higher in Santa Cruz $(p<0.001)$. Similarly, although the $\delta^{15} \mathrm{~N}$ values of the two species were similar within each estuary ( $p=0.804$; Fig. 4), the juveniles of $C$. hippos exhibited higher $\delta^{15} \mathrm{~N}$ values in overall $(11.03 \pm 1.10 \%$ ) than those of C. latus $(10.21 \pm 1.21 \%)$ due to differences in spatial distribution among them. 

according to the estuary (Fig. 3). Juvenile C. latus exhibited slightly wider isotopic niches than C. hippos in both Santa Cruz $\left(\mathrm{SEA}_{\mathrm{C}}=5.6 \% 0^{2}\right.$ for $C$. latus and $4.5 \%{ }^{2}$ for $C$. hippos $)$ and Sirinhaém $\left(\mathrm{SEA}_{\mathrm{C}}=7.9 \%{ }^{2}\right.$ for $C$. latus and $7.1 \%^{2}$ for $C$. hippos $)$, with high isotopic niche overlaps at both sites $\left(57.5 \%, \mathrm{CI}_{95 \%} 40.1-\right.$ 73.8\%, in Santa Cruz and 54.3\%, $\mathrm{CI}_{95 \%} 32.3-77.4 \%$, in Sirinhaém). Conversely, in Suape, where the two species had the most different isotopic niches, niche area was much wider in $C$. hippos $\left(\mathrm{SEA}_{\mathrm{C}}=9.5 \%{ }^{2}\right)$ than in $C$. latus $\left(\mathrm{SEA}_{\mathrm{C}}=2.7 \%^{2}\right)$. At this particular site, juvenile niche overlap between the two species was only of $27.13 \%\left(\mathrm{CI}_{95 \%} 11.5-45.0 \%\right)$, but the isotopic niche area $\left(\mathrm{SEA}_{\mathrm{C}}\right)$ of $C$. hippos covered up to $94.6 \%$ of that of $C$. latus. In the two remaining estuaries (Santa Cruz and Sirinhaém), the two species shared between 63 to $87 \%$ of their isotopic niche areas. 29.25 to $-14.50 \%$ and from -1.03 to $10.11 \%$, respectively, in the estuaries studied (Supplementary Table $\mathrm{S} 4$, Fig. 4). However, the variability in $\mathrm{C}$ and $\mathrm{N}$ isotopic ratios in the estuarine food webs depended greatly on the location: for example, the range in $\delta^{15} \mathrm{~N}$ values for organic matter source was the widest, but that in $\delta^{13} \mathrm{C}$ values the lowest, in Santa Cruz (Fig. 4).

\section{Discussion}

While differences in resource use within estuarine fish assemblages are thought to be largely modulated by species' functional traits (Albouy et al., 2011), closely related species are expected to display contrasted diets to allow their populations to co-exist in the wild (Ross, 1986). However, very few cross-sites comparisons were carry out so far to investigate diet plasticity for closely related fish species co-occurring in diverse biotic and environmental settings (e.g., Mariani et al. 2011). Our results bring new insights on this matter, by revealing site-related variations in the trophic ecology of the juveniles of two commercially important species from the Caranx genus with similar ecological features. Indeed, Caranx latus and C. hippos not only have similar shapes and growth trajectories (Viana et al., 2016), but also reproduce on deep reefs along the shelf (Heyman and Kjerfve, 2008), and mostly colonize estuaries as juveniles, before moving to deeper waters when adults (Smith-Vaniz, 2002). In the estuaries, their juveniles have been similarly reported to feed on a broad diversity of fish and crustaceans (Vasconcelos 
370

371

372

373

374

375

376

377

378

379

380

381

382

383

384

385

386

387

388

389

390

391

392

393

394

395

396

397

398

399

Filho et al., 2010; Medeiros et al., 2017), including key species in estuarine food webs (Ferreira, 2018; Lira et al., 2018). The present study however showed that, although gobies and decapod shrimps are the main food items ingested by both species, $C$. latus juveniles have a more piscivorous diet than those of $C$. hippos. These benthic prey represent a substantial part of the diet of juvenile jack species in general (Blaber and Cyrus, 1983; Smith and Parrish, 2002; Figueiredo and Pessanha, 2015; Medeiros et al., 2017) and are commonly eaten by other estuarine fish (Blaber, 1986; Vasconcelos Filho et al., 2003; Lira et al., 2017). The juveniles of the two species were also found to largely prey on pelagic fish like engraulids and clupeids in the three estuaries studied, as already reported from visual census studies in these ecosystems (Cermak, 2002). This indicates that, at least in estuaries, C. latus and C. hippos juveniles forage both at mid-water and directly above the substrate, feeding on a mix of pelagic and benthic prey.

\subsection{Variation in food sources during juvenile life}

Body size plays a central role in determining the type and size of the prey consumed by fish (Shelton et al., 1977), particularly in species like jacks that display schooling behaviors (Figueiredo and Menezes, 1980; Graham and Castellanos, 2005). Although a marked increase in piscivory has been reported for jacks at sizes above $200 \mathrm{~mm}$ SL (Blaber and Cyprus, 1983; Sudekum et al., 1991; Smith and Parrish, 2002), in this study, significant changes in diet composition due to increasing body size were only found for juvenile C. latus, and only consisted in small differences in the prey species ingested. The relatively low taxonomic precision for prey identification in the stomachs (particularly for small fish prey) may have hampered the power of our analysis. Yet, for both species, juvenile fish size did not seem to significantly be related to the size of the prey ingested. The diet of the two species thus seems to be fairly stable over the size range studied here $(35-157 \mathrm{~mm} \mathrm{SL})$. However, as major morphological changes in fish take place between the post-larval and juvenile stages (Nunn et al., 2012), dietary shifts in the two species might occur in smaller fish, i.e. before and during estuary colonization (Cocheret de la Morinière et al., 2003; Usmar, 2012). These dietary shifts can reflect either an increase in fish foraging ability as they grow, or changes in prey availability (Nunn et al., 2012). They probably also take place in larger fish, when they move towards offshore habitats (Cocheret de la Morinière et al., 2003).

Differences in environmental characteristics are also a major source of variation in the diet of fish, as they influences both the type and the availability of local food resources (Dineen et al., 2007; Jensen et al., 2008; Evangelista et al., 2014). Given the differences in food web structure and fish assemblages 
400

401

402

403

404

405

406

407

408

409

410

411

412

414

415

416

417

418

419

420

421

422

423

424

425

426

427

428

429

among the three estuaries studied, we expected the juveniles of the two species to display different food preferences and isotopic ratios among locations (Merigot et al., 2017; Silva-Júnior et al., 2017). However, although their prey preferences and isotopic niches varied from one estuary to the other, spatial differences in diet composition were surprisingly small, with only a greater consumption of fish (particularly of the Clupeidae and Engraulidae families) by C. hippos in Suape. As fish from different years and seasons were pooled in this work and because inter and intra-annual variations in food web composition and food availability may be significant in estuaries (e.g. Garcia et al. (2012) and Boucek and Rehage (2013)), seasonal processes might partly bias the results presented here, especially regarding the average isotopic compositions of jacks at each location. However, the $\delta^{13} \mathrm{C}$ and $\delta^{15} \mathrm{~N}$ values observed are within the ranges reported in other tropical estuaries, both for primary producers and for juvenile jacks (Abrantes et al., 2014; Claudino et al., 2015; Dolbeth et al., 2016). Their high variabilities suggest that the amplitude in $\delta^{13} \mathrm{C}$ and $\delta^{15} \mathrm{~N}$ isotopic compositions of the jacks at each estuary largely reflects those at the base of local food chains. Thus, in Suape and Sirinhaém, the wide range of $\delta^{13} \mathrm{C}$ values observed for organic matter sources is reflected in a greater range of $\delta^{13} \mathrm{C}$ values for the two jack species. Similarly, the higher $\delta^{15} \mathrm{~N}$ ratios of the juvenile jacks in Santa Cruz may partly reflect the incorporation of enriched ${ }^{15} \mathrm{~N}$ organic matter from coastal marine sources into the food web in this estuary, which has important connections with the marine realm (Flores Montes et al., 1998), although we cannot rule out this could indicate slightly higher trophic levels. Other sources may contribute to the local ${ }^{15} \mathrm{~N}$ enrichments such as agricultural and domestic wastes (Morris et al., 2015) given the proximity in the region of highly urbanized areas (CPRH, 2003).

Potential biases in diet composition obtained from SCA may arise from the caveats inherent to the technique. In particular, differences in digestion rates among prey and the difficulty to identify some of them when partly digested can lead to an over-estimation of the contribution of the food items with low digestion rates and to greater proportions of unidentified prey in the diet of carnivorous species (Hyslop, 1980). This could partly be the case in our study, as fish and crustaceans (i.e. relatively big prey with hard skeletons) are less easily digested than soft-bodied organisms (Buckland, et al., 2017). Moreover, sampling for SCA requires to match predators' local feeding strategies across time and space in order to produce a realistic image of their diets. Although this is yet to be demonstrated, feeding in juvenile jacks might also take place at times of the day not sampled during our survey. This would explain the high level of prey digestion in some of the stomachs analyzed and might have contributed to bias our results, by 
further precluding identification of the prey items with high digestibility. Within estuarine systems, the types and abundances of the prey available for foraging fish strongly vary according to habitat type (Svanbäck and Eklöv, 2002; Lecomte and Dodson, 2005; Cardozo et al., 2020), which partly contributes to diet changes in the predators exhibiting seasonal or size-related shifts in habitat use (Stevens et al., 2007; Ferreira et al., 2016; 2019). However, juvenile jacks are highly mobile within estuaries, using a wide diversity of estuarine habitats irrespective of their age (Medeiros et al., 2017). Moreover, the sampling design in this study attempted to capture most of the spatial and temporal variation in habitat use by the two species, by capturing juvenile jacks in all their main estuarine habitats (e.g. mangrove creeks, river banks) at each date, over multiple seasons and years. Because our sub-sampling strategy for SCA accounted for spatiotemporal differences in the abundances of the two species, among and within locations, the image of the global diet provided here should be rather realistic. Indeed, it reflects their habitat use but also the inter-annual and inter-seasonal variations in food source availability and food web structure in the three estuaries sampled, which are also likely to modulate fish diet composition (Boucek and Rehage, 2013; Garcia et al., 2017; Possamai et al., 2018).

\subsection{Possibility for trophic competition}

In estuaries, physico-chemical gradients (e.g. in salinity) drive food web structure and determine habitat suitability for fish (Barletta et al., 2008; da Silva et al., 2018). However, food abundance also modulates interactions between potential competitors (Sánchez-Hernández et al., 2017; Costa-Pereira et al., 2019). As a result, co-existing species tend to either share abundant food resources or differ in one or more dimensions of their environmental niche (Ross, 1986). One major caveat when evaluating resource partitioning between coexisting species is the measurement of only one dimension of their ecological niche (Costa-Pereira et al., 2019). With this regard, stable isotope analysis is a valuable complementary approach to common dietary methods (Silveira et al., 2020), calculating the isotopic niche as a proxy of the trophic niche (Newsome et al., 2007). However, although the position and the size of the isotopic niche of a species are primarily driven by variations in its diet, they can be influenced by its biology and physiology (Gorokhova, 2018; Karlson et al., 2018), and by habitat-driven differences in the isotope ratios of local food webs (Flaherty and Ben-David, 2010). In this study, SCA and SIA presented opposing results, especially in the Santa Cruz estuary where the greater difference in diet between the two species did not result in a reduction in their isotopic niche overlap. Moreover, the variability in $\delta^{13} \mathrm{C}$ values for both species at each site largely followed that of the organic matter sources present in the estuary. This 
460

461

462

463

464

465

466

467

468

469

470

471

472

473

474

475

476

477

478

479

480

481

482

483

484

485

486

487

488

489

suggests that the position and size of the isotopic niches for juvenile jacks in our study area largely reflect local variation in the isotopic signatures of their prey caused by local differences in food web structure. This confirms that the isotopic niche approach should be interpreted with caution, and does not necessarily provide accurate information to evaluate food partitioning between co-existing species (Flaherty and Ben-David, 2010; Petta et al, 2020; Shipley and Matich, 2020). Because tropical estuaries often exhibit a wide variety of organic matter sources and consumers, isotopic signals may be mixed along their food webs (Layman, 2007). Therefore, the isotopic niche approach might prove less valuable in these complex environments than in lakes or on land, where its application has been successful in elucidating biological processes at inter and intraspecific scales within food webs (Pettitt-Wade et al., 2015; Mumby et al., 2018; Sheppard et al., 2018; Costa-Pereira et al., 2019).

Resource partitioning has been reported for many fish species, and in diverse types of estuaries, including tropical ones (Pimentel and Joyeux, 2010; Le Loc'h et al., 2015; Moulton et al., 2017; Stevens et al., 2020). In the three estuaries studied here, although the two jack species had very similar prey and isotopic niches in overall, they exhibited slight spatial differences in their diet composition, which contributed to reduce the actual overlap in their niches at each studied location. This supports the idea that juvenile jacks adapt their feeding strategies to local food resources' availability in order to reduce trophic competition among them. This seems to occur in different ways though, depending on local environmental conditions. Indeed, although prey abundance was never directly assessed in any of the three estuaries studied, previous work concluded that Santa Cruz is that with the greatest fauna biodiversity in the area (Silva-Júnior et al., 2017). In particular, it sustains a wide variety of secondary consumers (Vasconcelos Filho et al., 2010; Ferreira, 2018), many of which are prey for juvenile jacks. In this rich environment, both $C$. latus and C. hippos juveniles occur at higher densities than in other estuaries (Paiva and Araújo, 2010, Silva-Júnior et al., 2017). They exhibit the most contrasting diets, but surprisingly also the most similar isotopic niches. Because the high diversity of secondary consumers in Santa Cruz allows many carnivores to feed upon both pelagic and benthic prey (Vasconcelos Filho et al., 2003), the local similarity in juvenile jacks' isotopic niches likely reflects the isotopic ratios of their fish and crustacean prey, as most of these are small predators feeding on both food chains. Thus, it appears that, when the diversity and availability of food is high like in Santa-Cruz, the juveniles of the two species avoid trophic competition by exploiting different prey, matching their respective diet preferences. Nonetheless, they apparently have to adapt these later and partially compete for food in less favorable 
490

491

492

493

494

495

496

497

498

499

500

501

502

503

504

505

506

507

508

509

510

511

512

513

514

515

516

517

518

519

environments. Indeed, in the Suape and Sirinhaém estuaries, where the diversity of available prey is limited, the two species focus on the same food resources. The greatest variability in their $\delta^{13} \mathrm{C}$ ratios at these sites indicates that they rely on a broader number of food chains though, including those based on allochthonous sources of organic matter, like freshwater inputs (Abrantes and Sheaves, 2010). This diversification of carbon sources can be seen as an ecological response to reduce competition between species (Lecomte and Dodson, 2005). It might allow C. latus and C. hippos to co-exist in Suape and Sirinhaém in spite of their similarities in diet. The fact that the abundances of both C. latus and C. hippos juveniles are lower in these two estuaries suggests that the higher trophic niche overlap observed at these sites result in an increased competition for food among them. However, further information on the temporal fluctuations in prey abundance and the timing of their consumption is needed before one can conclude about the actual intensity of this phenomenon. First, trophic competition between fish species with similar global diets can be reduced when these later largely reflect an opportunistic use of seasonal peaks in the abundances of the most shared prey (Lucena et al., 2000; Boucek and Rehage, 2013). This might very well be the case here, especially as this kind of opportunistic feeding behavior would explain the variability in $\delta^{13} \mathrm{C}$ ratios observed for both species. Differences in feeding rhythms between $C$. latus and $C$. hippos may also reduce the intensity of the trophic competition among their juveniles at the daily scale, as already observed for other jack species (Blaber and Cyrus, 1983). Lastly, competition for food is also often avoided through differences in the periods for juvenile occurrence in the estuaries, as observed in local snook species with similar diets but distinct spawning periods (Stevens et al., 2020). However, this does not really apply here as $C$. latus and C. hippos in northeastern Brazil both are expected to spawn from April to June (Heyman and Kjerfve, 2008), and their juveniles are mostly fished in local estuaries during the late summer (McBride and McKown, 2000; Vilar et al., 2011; da Silva et al., 2018).

\section{Conclusion}

This study contributes to better understanding the drivers of juvenile trophic ecology and its variation in tropical estuaries. Although the two close species of jacks studied here apparently globally rely on similar prey during their juvenile estuarine life, our results revealed some plasticity in their resource use, supporting the idea that resource partitioning processes between sympatric species are locally dependent (Costa-Pereira et al., 2019). Such plasticity in resource use according to local food web structure may not only favor the coexistence of a larger number of species but also provide greater 
stability for estuarine food webs (Kondoh, 2003). In order to evaluate it, cross-sites comparisons should be systematically undertaken when investigating the trophic ecology of sympatric fish species,

522 particularly in tropical estuaries that show a high diversity of food sources (Layman, 2007). As spatial variation in the trophic ecology of predators like C. latus and C. hippos may not only influence the growth and survival of their juveniles, but also modulate their respective roles in the functioning of estuarine food webs, such cross-sites comparisons could be key for evaluating the implications of different co-existence scenarios, not only on the maintenance of coastal fish stocks but also on the composition and functioning of estuarine systems. This should be undertaken keeping in mind that both anthropic pressures and Climate Change may displace the environmental boundaries of estuaries or alter the composition and productivity of their food webs (Araújo et al. 2016, Chevillot et al. 2019), thereby affecting the way fish species exploit estuarine resources and modifying their roles in food webs.

531

This study was funded in part by the CNPq (National Council for Scientific and Technological Development, CNPq n 479845/2013-1, n 407125/2013-2 and $n^{\circ}$ 207786/2015-1; research grants for Thierry Frédou (n 307422/2020-8) and Flávia Lucena Frédou (n 308544/2019-1)), the "Fundação de Amparo à Ciência e Tecnologia do Estado de Pernambuco" (FACEPE/CAPES APQ 0146-2.05/17), the Universidade Federal Rural de Pernambuco (UFRPE 015/2018) and by CAPES (Coordination for the Improvement of Higher Education Personnel) for providing the scholarship to the first author. We thanks to the members of BIOIMPACT Laboratory for their efforts on field campaigns and sampling procedures.

540 This article is a contribution to the PADDLE project, which has received funding from the European 541 Union's Horizon 2020 research and innovation program under grant agreement No 734271, to the LMI

542 TAPIOCA and to the SMAC project (CAPES/COFECUB n 88881.142689/2017-01).

\section{References}

544 Abrantes, K. G., A. Barnett and S. Bouillon, 2014. Stable isotope-based community metrics as a tool to identify patterns in food web structure in east African estuaries. Functional Ecology 28: 270-282. doi: $10.1111 / 1365-2435.12155$

Abrantes, K. G. and M. Sheaves, 2010. Importance of freshwater flow in terrestrial-aquatic energetic connectivity in intermittently connected estuaries of tropical Australia. Marine Biology 157: 20712086. doi: $10.1007 / \mathrm{s} 00227-010-1475-8$

Albouy, C., F. Guilhaumon, S. Villéger, M. Mouchet, L. Mercier, J. M. Culioli, J. A. Tomasini, F. Le Loc'h and D. Mouillot, 2011. Predicting trophic guild and diet overlap from functional traits: Statistics, opportunities and limitations for marine ecology. Marine Ecology Progress Series 436:17- 
Anderson, M. J., 2001. A new method for non-parametric multivariate analysis of variance. Austral Ecology, 26: 32-46. doi:10.1111/j.1442-9993.2001.01070.pp.x

Araújo, F. G., M. C. C. De Azevedo, and A. P. P. Guedes, 2016. Inter-decadal changes in fish communities of a tropical bay in southeastern Brazil. Regional Studies in Marine Science 3: 107-118. doi: 10.1016/j.rsma.2015.06.001

560

[dataset] APAC, 2019. Sistema de Geoinformação Hidrometeorológico de Pernambuco, Agência Pernambucana de Águas e Clima. available at: http://www.apac.pe.gov.br/sighpe/

Barletta, M., C. S. Amaral, M. F. M. Corrêa, F. Guebert, D. V. Dantas, L. Lorenzi, and U. Saint-Paul, 2008. Factors affecting seasonal variations in demersal fish assemblages at an ecocline in a tropicalsubtropical estuary. Journal of Fish Biology 73: 1314-1336. doi: 10.1111/j.1095-8649.2008.02005.x Economo, J. Ferreira, B. Guénard, C. G. Leal, V. Isaac, A. C. Lees, C. L. Parr, S. K. Wilson, P. J. Young, and N. A. J. Graham, 2018. The future of hyperdiverse tropical ecosystems. Nature 559: $517-$ 526. doi: $10.1038 / \mathrm{s} 41586-018-0301-1$

Bearhop, S., C.E. Adams, S. Waldron, R.A. Fuller, and H. Macleod, 2004. Determining trophic niche width: A novel approach using stable isotope analysis. Journal of Animal Ecology 73: 1007-1012. doi:10.1111/j.0021-8790.2004.00861.x

Beck, M. W., K. L. Heck, K. W. Able, D. L. Childers, D. B. Eggleston, B. M. Gillanders, B. Halpern, C. G. Hays, K. Hoshino, T. J. Minello, R. J. Orth, P. F. Sheridan, and M. P. Weinstein, 2001. The Identification, Conservation, and Management of Estuarine and Marine Nurseries for Fish and Invertebrates. BioSience 51: 633-641.

Bezerra Junior, J. L, X. G. Diaz, and S. Neumann-Leitão, 2011. Diversidade de larvas de peixes das áreas internas e externas do porto de Suape (Pernambuco - Brazil). Tropical Oceanography Online 39: 1-13.

Blaber, S. J. M., 1986. Feeding selectivity of a guild of piscivorous fish in mangrove areas of north-west Australia. Marine and Freshwater Research 37: 329-336. doi: 10.1071/MF9860329

Blaber, S. J. M., 1997. Fish and fisheries in tropical estuaries. Vol. 22. Springer Science \& Business Media, 367p. Marine Science 80: 457-472. 
583

584

585

586

587

588

589

590

591

592

593

594

595

596

597

598

599

600

601

602

603

604

605

606

607

608

609

610

611

612

Blaber, S. J. M., 2013. Fishes and fisheries in tropical estuaries: The last 10 years. Estuarine, Coastal and Shelf Science 135: 57-65. doi: 10.1016/j.ecss.2012.11.002

Blaber, S.J.M. and M. Barletta, 2016. A review of estuarine fish research in South America: what has been achieved and what is the future for sustainability and conservation?. Journal of Fish Biology 89: 537-568. doi:10.1111/jfb.12875

Blaber, S. J. M., and D. P. Cyrus, 1983. The biology of Carangidae (Teleostei) in Natal estuaries. Journal of Fish Biology 22: 173-188.

Borges, G.C.P., 2011. Comunidade fitoplanctônica do estuário do Rio Massangana (Pernambuco Brasil). MSc Thesis, Univ. Federal de Pernambuco, Brazil, unpublised.

Boucek, R. E., and J. S. Rehage, 2013. No free lunch: Displaced marsh consumers regulate a prey subsidy to an estuarine consumer. Oikos 122: 1453-1464. doi: 10.1111/j.1600-0706.2013.20994.X

Buckland, A., R. Baker, N. Loneragan and M. Sheaves, 2017. Standardising fish stomach content analysis: The importance of prey condition. Fisheries Research 196: 126-140. doi: 10.1016/j.fishres.2017.08.003.

Canty A. and B. D. Ripley, 2020. boot: Bootstrap R (S-Plus) Functions. R package version 1.3-25

Cardozo, A. L. P., B. A. Quirino, K. Y. Yofukuji, M. H. F. Aleixo and R. Fugi, 2020. Habitat complexity and individual variation in diet and morphology of a fish species associated with macrophytes. Ecology of Freshwater Fish 00: 1-13. doi: 10.1111/eff.12574

Cermak, M. J., 2002. Caranx latus (Carangidae) Chooses Dock Pilings to Attack Silverside Schools: A Tactic to Interfere With Stereotyped Escape Behavior of Prey? The Biological Bulletin 203: 241-243. doi: doi.org/10.2307/1543419

Chevillot, X., S. Tecchio, J. Selleslagh, G. Bachelet, N. Niquil, and B. Sautour, 2019. Global Changes Jeopardize the Trophic Carrying Capacity and Functioning of Estuarine Ecosystems. 473-495. doi: $10.1007 / \mathrm{s} 10021-018-0282-9$

Claudino, M.C., A. L. M. Pessanha, F. G. Araújo, and A.M. Garcia, 2015. Trophic connectivity and basal food sources sustaining tropical aquatic consumers along a mangrove to ocean gradient. Estuarine, Coastal and Shelf Science 167, 45-55. doi:10.1016/j.ecss.2015.07.005

Cocheret de la Morinière, E., B. J. A. Pollux, I. Nagelkerken, M. A. Hemminga, A. H. L. Huiskes and G. van der Velde, 2003. Marine Ecology Progress Series 246: 279-289.

Costa-Pereira R., M. S. Araújo Márcio, F. L. Souza and T. Ingram, 2019. Competition and resource 
breadth shape niche variation and overlap in multiple trophic dimensions. Proceedings of the Royal Society B 286: 20190369. doi: 10.1098/rspb.2019.0369

CPRH, 2003. Diagnóstico socioambiental do litoral Norte de Pernambuco. Agência Estadual do Meio Ambiente, Recife, 214 pp.

CPRH, 2003a. Diagnóstico socioambiental do litoral Sul de Pernambuco. Agência Estadual do Meio Ambiente, Recife, $87 \mathrm{pp}$.

da Silva, V. E. L., E. C. Teixeira, V. S. Batista, and N. N. Fabré, 2018. Spatial distribution of juvenile fish species in nursery grounds of a tropical coastal area of the south-western Atlantic. Acta Ichthyologica et Piscatoria 48: 9-18. doi: 10.3750/AIEP/02299

Dahlgren, C. P., G. T. Kellison, A. J. Adams, B. M. Gillanders, M. S. Kendall, C. A. Layman, J. A. Ley, I. Nagelkerken, and J. E. Serafy, 2006. Marine nurseries and effective juvenile habitats : concepts and applications. 312: 291-295.

Dineen, G., S.S.C. Harrison and P. S. Giller, 2007. Diet partitioning in sympatric Atlantic salmon and brown trout in streams with contrasting riparian vegetation. Journal of Fish Biology 71: 17-38. doi:10.1111/j.1095-8649.2007.01441.x

Doi, H., K. H. Chang, T. Ando, I. Ninomiya, H. Imai, and S. I. Nakano, 2009. Resource availability and ecosystem size predict food-chain length in pond ecosystems. Oikos 118: 138-144. doi: $10.1111 / \mathrm{j} .1600-0706.2008 .17171 . x$

Dolbeth, M., A. L. Vendel, A. Baeta, A. Pessanha and J. Patrício, 2016. Exploring ecosystem functioning in two Brazilian estuaries integrating fish diversity, species traits and food webs. Marine Ecology Progress Series 560: 41-55. doi: 10.3354/meps11895

Evangelista, C., A. Boiche, A. Lecerf and J. Cucherousset, 2014. Ecological opportunities and intraspecific competition alter trophic niche specialization in an opportunistic stream predator. Journal of Animal Ecology 83: 1025-1034. doi:10.1111/1365-2656.12208

FAO, 2018. The state of world fisheries and aquaculture 2018 - meeting the sustainable development goals. Food and Agriculture Organization, Rome.

Ferreira, V., 2018. Estrutura trófica da ictiofauna estuarina e marinha do complexo Itapissuma/Itamaracá, Norte de Pernambuco, Brasil. PhD Thesis, Univ. Federal Rural de Pernambuco, Brazil, unpublised.

Ferreira V., F. Le Loc'h, F. Ménard, T. Frédou, and F.L. Frédou, 2019. Composition of the fish fauna in a tropical estuary: the ecological guild approach. Scientia Marina 83: 133-142. doi: 
Figueiredo, J. A. de, K. Muniz, S. J. De Macêdo, M. D. J. F. Montes, and F. A. D. N. Feitosa, 2006.

645

646

647

648

649

650

651

652

653

654

655

656

657

658

659

660

661

662

663

664

665

666

667

668

669

670

671

672
Hidrologia E Biomassa Fitoplanctônica Nas Barras Orange E Catuama (Canal De Santa Cruz), Em Itamaracá-PE: Variação Nictemeral. Arquivos de Ciências do Mar 39: 5-17. doi: 10.32360/acmar.v39i1-2.6152

Figueiredo, G. G. A. A., and A. L. M. Pessanha, 2015. Comparative study of trophic organization of juvenile fish assemblages of three tidal creeks in a tropical semi-arid estuary. Journal of Fish Biology 89: 680-695. doi: 10.1111/jfb.12844.

Figueiredo, J. L., and N. A. Menezes, 1980. Manual de Peixes Marinhos do Sudeste do Brasil. IV. Teleostei (3). Museu de Zoologia, Universidade de São Paulo, São Paulo.

Flaherty, E. A., and M. Ben-David, 2010. Overlap and partitioning of the ecological and isotopic niches. Oikos 119: 1409-1416. doi: 10.1111/j.1600-0706.2010.18259.x

Flores Montes, M. D. J., S. J. de Macêdo, M. L. Koening, and I. Lins Correia, 1998. Variação nictemeral do fitoplâncton e elementos nutrientes no canal de Santa Cruz, Itamaracá - PE - Brasil. Tropical Oceanography 26: 13-26. doi: 10.5914/tropocean.v26i1.2745

França, S., R. P. Vasconcelos, V. F. Fonseca, S. E. Tanner, P. Reis-Santos, M. J. Costa, and H. N. Cabral, 2012. Predicting fish community properties within estuaries: Influence of habitat type and other environmental features. Estuarine, Coastal and Shelf Science 107: 22-31. doi: 10.1016/j.ecss.2012.04.013

Fry, B., 2006. Stable Isotope Ecology. Springer, New York, 308 pp.

Garcia, A. M., J. P. Vieira, K. O. Winemiller, L. E. Moraes and E. T. Paes, 2012. Factoring scales of spatial and temporal variation in fish abundance in a subtropical estuary. Marine Ecology Progress Series 461: 121-135.

Garcia, A. M., M. C. Claudino, R. Mont'Alverne, P. E. R. Pereyra, M. Copertino and J. P. Vieira, 2017. Temporal variability in assimilation of basal food sources by an omnivorous fish at Patos Lagoon Estuary revealed by stable isotopes (2010-2014). Marine Biology Research 13: 98-107. doi: $10.1080 / 17451000.2016 .1206939$

Gillanders, B. M., C. Izzo, Z. A. Doubleday and Q. Ye, 2015. Partial migration: growth varies between resident and migratory fish. Biology Letters 11: 20140850.

Gonzalez J. G., F. Ménard, F. Le Loc’h, H. A. de Andrade, A. P. Viana, V. Ferreira, F. Lucena-Frédou, 
A. S. Lira, J. M. Munaron, and T. Frédou, 2019. Trophic resource partitioning of two snook fish species (Centropomidae) in tropical estuaries in Brazil as evidenced by stable isotope analysis. Estuarine Coastal and Shelf Science 226: 106287. doi: 10.1016/j.ecss.2019.106287

Gorokhova, E., 2018. Individual growth as a non-dietary determinant of the isotopic niche metrics. Methods in Ecology and Evolution 9: 269-277. doi: 10.1111/2041-210X.12887

Graham, R. T., and D. W. Castellanos, 2005. Courtship and spawning behaviors of carangid species in Belize. Fishery Bulletin. 103: 426-432.

Guimarães, A. S., P. Travassos, P. W. M. E. Souza Filho, F. D. Gonçalves, and F. Costa, 2010. Impact of aquaculture on mangrove areas in the northern Pernambuco Coast (Brazil) using remote sensing and geographic information system. Aquaculture Research 41: 828-838. doi: 10.1111/j.13652109.2009.02360.x

Ferreira, G. V. B., M. Barletta, A. R. A. Lima, D. V. Dantas, A. K. S. Justino and M. F. Costa, 2016 Plastic debris contamination in the life cycle of Acoupa weakfish (Cynoscion acoupa) in a tropical estuary, ICES Journal of Marine Science 73: 2695-2707. doi: 10.1093/icesjms/fsw108

Ferreira, G. V. B., M. Barletta and A.R.A. Lima, 2019. Use of estuarine resources by top predator fishes. How do ecological patterns affect rates of contamination by microplastics? Science of The Total Environment 655: 292 - 304. doi: 10.1016/j.scitotenv.2018.11.229.

Harrison, T. D., and A. K. Whitfield, 2006. Estuarine Typology and the Structuring of Fish Communities in South Africa. Environmental Biology of Fishes 75: 269-293. doi: 10.1007/s10641-006-0028-y.

Harrison, T. D., and A. K. Whitfield, 2012. Fish trophic structure in estuaries, with particular emphasis on estuarine typology and zoogeography. Journal of Fish Biology 81: 2005-2029. doi: 10.1111/j.10958649.2012.03458.x

Hastenrath, S., 2012. Exploring the climate problems of Brazil's Nordeste: a review. Climate Change 112: 243-251. doi: 10.1007/s10584-011-0227-1

Herzka, S. Z., 2005. Assessing connectivity of estuarine fishes based on stable isotope ratio analysis. Estuarine, Coastal and Shelf Science 64: 58-69. doi: 10.1016/j.ecss.2005.02.006

Heyman, W. D., and B. Kjerfve, 2008. Characterization of transient multi-species reef fish spawning aggregations at Gladden Spit, Belize. Bulletin of Marine Science 83: 531-551.

Hiraoka, Y., K. Fujioka, H. Fukuda, M. Watai and S. Ohshimo, 2019. Interannual variation of the diet shifts and their effects on the fatness and growth of age - 0 Pacific bluefin tuna (Thunnus orientalis) 
703

704

705

706

707

708

709

710

711

712

713

714

715

716

off the southwestern Pacific coast of Japan. Fisheries Oceanography 28: 419-433. doi: $10.1111 /$ fog. 12421

Hoeinghaus, D. J., J. P. Vieira, C. S. Costa, C. E. Bemvenuti, K. O. Winemiller, and A. M. Garcia, 2011. Estuary hydrogeomorphology affects carbon sources supporting aquatic consumers within and among ecological guilds. Hydrobiologia 673: 79-92. doi: 10.1007/s10750-011-0751-z

Hofling, J. C., L. Ishikawa Ferreira, F. B. Ribeiro Neto, A. M. Paiva Filho, C. P. Soares, and M. S. R. da Silva, 1998. Fish alimentation of the Carangidae family of the estuarine lagoon complex in Cananéia, São Paulo, Brazil. Revista Bioikos 12: 7-18.

Hounsou-gbo, G. A, M. Araujo, B. Bourlès, D. Veleda, and J. Servain, 2015. Tropical Atlantic Contributions to Strong Rainfall Variability Along the Northeast Brazilian Coast. Advances in Meteorology 2015: 902084. doi: 10.1155/2015/902084

Hureau, J. C., 1970. Biologie comparée de quelques Poissons antarctiques (Nototheniidae), vol. 68. Bulletin de l'Instut Océanographique, Monaco, pp. 241-244.

Hyslop, E. J., 1980. Stomach contents analysis - a review of methods and their application. Journal of Fish Biology 17: 411-429. doi: 10.1111/j.1095-8649.1980.tb02775.x.

Isnard, E., J. Tournois, D. J. Mckenzie, F. Ferraton, N. Bodin, C. Aliaume and A. Darnaude, 2015. Getting a Good Start in Life? A Comparative Analysis of the Quality of Lagoons as Juvenile Habitats for the Gilthead Seabream Sparus aurata in the Gulf of Lions. Estuaries and Coasts 38: 1937-1950. doi: $10.1007 / \mathrm{s} 12237-014-9939-6$

Jackson, A. A., and A. Parnell, 2016. Package "SIBER" - Stable Isotope Bayesian Ellipses in R. R Package Version 2.0.3.

Jackson, A. L., R. Inger, A. C. Parnell, and S. Bearhop, 2011. Comparing isotopic niche widths among and within communities: SIBER - Stable Isotope Bayesian Ellipses in R. Journal of Animal Ecology 80: 595-602. doi:10.1111/j.1365-2656.2011.01806.x

Jensen, H., K. K. Kahilainen, P.-A. Amundsen, K. O. Gjelland, A. Tuomaala, T. Malinen and T. Bohn, 2008. Predation by brown trout (Salmo truta) along a diversifying prey community gradient. Canadian Journal of Fisheries and Aquatic Sciences 65: 1831-1841. doi: 10.1139/F08-096

Karlson, A. M. L., M. Reutgard, A. Garbaras and E. Gorokhova, 2018. Isotopic niche reflects stressinduced variability in physiological status. Royal Society Open Science 5: 171398. doi: $10.1098 /$ rsos. 171398 
733

734

735

736

737

738

739

740

741

742

743

744

745

746

747

748

749

750

751

752

753

754

755

756

757

758

759

760

761

762

Kondoh, M., 2003. Foraging Adaptation and the Relationship Between Food-Web Complexity and Stability. Science 299: 1388-1391. doi: 10.1126/science.1079154

Layman, C. A., 2007. What can stable isotope ratios reveal about mangroves as fish habitat?. Bulletin of Marine Science 80: 513-527.

Le Loc'h F., J. D. Durand, K. Diop and J. Panfili, 2015. Spatio-temporal isotopic signatures $\left(\delta^{13} \mathrm{C}\right.$ and $\delta^{15} \mathrm{~N}$ ) reveal that two sympatric West African mullet species do not feed on the same basal production sources. Journal of Fish Biology 86: 1444-1453. doi: 10.1111/jfb.12650

Le Pape, O., and S. Bonhommeau, 2015. The food limitation hypothesis for juvenile marine fish. Fish and Fisheries 16: 373-398. doi: 10.1111/faf.12063

Lecomte, F., and J. J. Dodson, 2005. Distinguishing trophic and habitat partitioning among sympatric populations of the estuarine fish Osmerus mordax Mitchill. Journal of Fish Biology 66:1601-1623. doi: $10.1111 / \mathrm{j} .1095-8649.2005 .00702 . x$

Lira, A. S., R. Angelini, F. Le Loc'h, F. Ménard, C. Lacerda, T. Frédou, and F. L. Frédou, 2018. Trophic flow structure of a neotropical estuary in northeastern Brazil and the comparison of ecosystem model indicators of estuaries. Journal of Marine Systems 182: 31-45. doi: 10.1016/j.jmarsys.2018.02.007.

Lira, A. S., F. L. Frédou, A. P. Viana, L. N. Eduardo, and T. Frédou, 2017. Feeding ecology of Centropomus undecimalis (Bloch, 1792) and Centropomus parallelus (Poey, 1860) in two tropical estuaries in Northeastern Brazil. Pan-American Journal of Aquatic Sciences 12: 123-135.

Losos, J. B., 2000. Ecological character displacement and the study of adaptation. Proceedings of the National Academy of Sciences of the United States of America 97: 5693-5695.

Lucena, F.M., T. Vaske Jr, J. R. Ellis, and C. M. O’Brien, 2000. Seasonal variation in the diets of bluefish, Pomatomus saltatrix (Pomatomidae) and striped weakfish, Cynoscion guatucupa (Sciaenidae) in southern Brazil: implications of food partitioning. Environmental Biology of Fishes $57,423-434$.

Mariani, S., C. Boggan and D. Balata, 2011. Food resource use in sympatric juvenile plaice and flounder in estuarine habitats. Marine Ecology 32: 96-101. doi: 10.1111/j.1439-0485.2010.00419.x

Martínez Del Rio, C., N. Wolf, S. A. Carleton, and L. Z. Gannes, 2009. Isotopic ecology ten years after a call for more laboratory experiments. Biological Reviews 84: 91-111. doi: 10.1111/j.1469185X.2008.00064.X

McBride, R. S. and K. A. McKown, 2000. Consequences of dispersal of subtropically spawned crevalle 
jacks, Caranx hippos, to temperate estuaries. Fishery Bulletin 98: 528-538.

Medeiros, A. P. M. de, J. H. de A. Xavier, and I. M. de L. Rosa, 2017. Diet and trophic organization of the fish assemblage from the Mamanguape River Estuary, Brazil. Latin American Journal of Aquatic Research 45: 879-890. doi: 10.3856/vol45-issue5-fulltext-2

Medeiros, C., and B. Kjerfve, 1993. Hydrology of a Tropical Estuarine System: Itamaracá, Brazil. Estuarine, Coastal and Shelf Science 36: 495-515.

Medeiros, C., B. Kjerfve, M. Araujo, and S. Neumann-Leitão, 2001. The Itamaracá Estuarine Ecosystem, Brazil. In: Seeliger, U. and B. Kjerfve (Eds.), Coastal Marine Ecosystem of Latin America (Ecological Studies). Springer, New York, pp. 71-82. doi:10.1007/978-3-662-04482-7

Merigot, B., F. Lucena Frédou, A. P. Viana, B. P. Ferreira, E. do N. Costa Junior, C. A. B. da SilvaJúnior, and T. Frédou, 2017. Fish assemblages in tropical estuaries of Northeast Brazil: a multicomponent diversity approach. Ocean and Coastal Management 143: 175-183. doi: 10.1016/j.ocecoaman.2016.08.004

Mitra, A., and S. Zaman, 2016. Threats to Marine and Estuarine Ecosystems. In: Basics of Marine and Estuarine Ecology. Mitra, A. and S. Zaman (Eds). Springer, New York, 365-417.

Morris, C., S. Y. Lee and J. van de Merwe, 2015. $\delta^{15} \mathrm{~N}$ of estuarine fishes as a quantitative indicator of urbanization. Ecological Indicators 56: 41-49. doi: 10.1016/j.ecolind.2015.03.028

Moulton, D. L., M. A. Dance, J. A. Williams, M. Z. Sluis, G. W. Stunz and J. R. Rooker, 2017. Habitat Partitioning and Seasonal Movement of Red Drum and Spotted Seatrout. Estuaries and Coasts 40: 905-916. doi: 10.1007/s12237-016-0189-7

MPA, 2011. Boletim Estatístico Da Pesca E Aquicultura - 2011. Ministério da Pesca e Aquicultura, Brasília, 59 pp.

Mumby, J. A., S. M. Larocque, T. B. Johnson, T. J. Stewart, J. D. Fitzsimons, B. C. Weidel, M. G. Walsh, J. R. Lantry, M. J. Yuille and A. T. Fisk, 2018. Diet and trophic niche space and overlap of Lake Ontario salmonid species using stable isotopes and stomach contents. Journal of Great Lakes Research 44:1383-1392. doi: 10.1016/j.jglr.2018.08.009

Nagelkerken, I., G. van der Velde, M. W. Gorissen, G. J. Meijer, T. Van’t Hof, and C. den Hartog, 2000. Importance of Mangroves, Seagrass Beds and the Shallow Coral Reef as a Nursery for Important Coral Reef Fishes, Using a Visual Census Technique. Estuarine, Coastal and Shelf Science 51: 31-44, doi: $10.1006 /$ ecss. 2000.0617 
793

794

795

796

797

798

799

800

801

802

803

804

805

806

807

808

809

810

811

812

813

814

815

816

817

818

819

820

821

822

Neumann-Leitão, S., R. Schwamborn, S. J. Macêdo, C. Medeiros, M. L. Koening, M. J. F. Montes, F. A. N. Feitosa, and L. M. O. Gusmão, 2001. Plankton dynamics at Itamaracá mangrove estuarine system, Pernambuco, Brazil. In: Villacampa, Y., C. A. Brebbia, and J. L. Usó (Eds), Ecosystems and Sustainable Development III. W.I.T. Press, Southampton, pp. 435-445.

Newsome, S.D., C. Martinez del Rio, S. Bearhop, and D. L. Phillips, 2007. A Niche for Isotope Ecology. Frontiers in Ecology and the Environment 5: 429-436. doi:10.1890/060150.01

Nunn, A. D., L. H. Tewson, and I. G. Cowx, 2012. The foraging ecology of larval and juvenile fishes. Reviews in Fish Biology and Fisheries 16: 377-408. doi: 10.1111/faf.12063

Oksanen, J., F. G. Blanchet, M. Friedly, R. Kindt, P. Legendre, D. Mcglinn, P. R. Minchin, R. B. O’hara, G. L. Simpson, P. Solymos; M. H. H. Stevens, E. Szoecs, and H. Wagber, 2017. vegan: Community Ecology Package. R package version 2.4-0.

Ogden, J. C., I. Nagelkerken, and C. C. McIvor, 2014. Connectivity in the tropical coastal seascape. Implications for marine spatial planning and resource management. In: Interrelationships Between Corals and Fisheries. Bortone, S. A. (Eds), CRC Press, Boca Raton, 253-273.

Paiva, A.C. G. de, and M. E. de Araújo, 2010. Environmental characterization and spatial distribution of fish fauna in estuaries in the state of Pernambuco, Brazil. Tropical Oceanography 38: 1-46.

Petta, J. C., O. N. Shipley, S. P. Wintner, G. Clif, M. L. Dicken and N. E. Hussey, 2020. Are you really what you eat? Stomach content analysis and stable isotope ratios do not uniformly estimate dietary niche characteristics in three marine predators. Oecologia 192: 1111-1126. doi: 10.1007/s00442-020$04628-6$

Pettitt-Wade, H., K. W. Wellband, D. D. Heath and A. T. Fisk, 2015. Niche plasticity in invasive fishes in Great Lakes. Biological Invasions 17: 2565-2580. doi: 10.1007/s10530-015-0894-3

Pimentel, C. R. and J. C. Joyeux, 2010. Diet and food partitioning between juveniles of mutton Lutjanus analis, dog Lutjanus jocu and lane Lutjanus synagris snappers (Perciformes: Lutjanidae) in a mangrove-fringed estuarine environment. Journal of Fish Biology 76: 2299-2317. doi: 0.1111/j.10958649.2010.02586.x

Pinnegar, J.K., and N. V. C. Polunin, 1999. Differential fractionation of $\delta^{13} \mathrm{C}$ and $\delta^{15} \mathrm{~N}$ among fish tissues: Implications for the study of trophic interactions. Functional Ecology 13: 225-231. doi:10.1046/j.1365-2435.1999.00301.x

Pinnegar, J. K., and N. V. C. Polunin, 2000. Contributions of stable-isotope data to elucidating food webs 
Possamai, B., J. P. Vieira, A. M. Grimm and A. M. Garcia, 2018. Temporal variability (1997-2015) of trophic fish guilds and its relationships with El Niño events in a subtropical estuary. Estuarine, Coastal and Shelf Science 202: 145-154. doi: 10.1007/s12237-019-00693-0

Post, D. M., 2002. Using stable isotopes to estimate trophic position: models, methos, and assumptions. . Ecology 83: 703-718. doi: 10.2307/3071875

R Core Team. 2019. R: A Language and Environment for Statistical Computing.

Riera, P., and P. Richard, 1996. Isotopic Determination of Food Sources of Crassostrea gigas Along a Trophic Gradient in the Estuarine Bay of Marennes-Oléron. Estuarine, Coastal and Shelf Science 42: 347-360. doi: 10.1006/ecss.1996.0023

Ross, S. T., 1986. Resource Partitioning in Fish Assemblages: A Review of Field Studies. American Society of Ichthyologists and Herpetologists 2: 352-388.

Sánchez-Hernández, J., A. P. Eloranta, A. G. Finstad and P.-A. Amundsen, 2017. Community structure affects trophic ontogeny in a predatory fish. Ecology and Evolution 7: 358-367. doi: $10.1002 /$ ece 3.2600

Schoener, T. W., 1974. Resource Partitioning in ecological communities. Science185: 27-39. doi: 10.1126/science.185.4145.27

Sheaves, M., 2009. Consequences of ecological connectivity : the coastal ecosystem mosaic. 391: 107115. doi: $10.3354 / \mathrm{meps} 08121$

Sheaves M., R. Baker, I. Nagelkerken and R. M. Connolly, 2015. True Value of Estuarine and Coastal Nurseries for Fish: Incorporating Complexity and Dynamics. Estuaries and Coasts 38: 401-414. doi: $10.1007 / \mathrm{s} 12237-014-9846-\mathrm{x}$

Shelton, R. W., W. Sutcliffe Jr., and M. A. Paranjape, 1977. Structure of pelagic food chain and relationship between plankton and fish production. Journal of the Fisheries Research Board of Canada 34, 2344-2353.

Sheppard, C. E., R. Inger, R. A. McDonald, S. Barker, A. L. Jackson, F. J. Thompson, E. I. K.

852 Shipley, O. N. and P. Matich, 2020. Studying animal niches using bulk stable isotope ratios: an updated 
Silva-Júnior, C. A. B., B. Mérigot, F. Lucena-Frédou, B. P. Ferreira, M. S. Coxey, S. M. Rezende, and T. Frédou, 2017. Functional diversity of fish in tropical estuaries: A traits-based approach of communities in Pernambuco, Brazil. Estuarine, Coastal and Shelf Science 198: 413-420. doi:

Silva, J. B. Da, J. D. Galvíncio, A. C. D. B. Corrêa, D. G. Da Silva, and C. C. C. Machado, 2011. Classificação Geomorfológica dos Estuários do Estado de Pernambuco (Brasil) com Base em Imagens do LANDSAT 5/TM. Revista Brasileira de Geografia Física 4: 118-133.

Silva, M.H. da, 2009. Estrutura e produtividade da comunidade fitoplanctônica de um estuário tropical (Sirinhaém, Pernambuco, Brasil). Ph.D Thesis, Univ. Federal de Pernambuco, Brazil, unpublised.

Silva, M. L., F. A. N Feitosa, M. J. Flores-Montes, A. Y. Otsuka, F. Saldanha-Côrrea, and C. Noriega, 2019. Phytoplankton Productivity and Hydrology in an Impacted Estuarine Complex in Northeastern Brazil. Open Journal of Ecology 9: 458-477. doi: 10.4236/oje.2019.910030

Silveira, E. L. da, N. Semmar, J. E. Cartes, V. M. Tuset, A. Lombarte, E. L. C. Ballester and A. M. Vazdos-Santos, 2020. Methods for Trophic Ecology Assessment in Fishes: A Critical Review of Stomach Analyses. Reviews in Fisheries Science and Aquaculture 28: 71-106. doi: $10.1080 / 23308249.2019 .1678013$

Smith-Vaniz, W. F., 2002. Carangidae. In: The Living Marine Resources of the Western Central Atlantic, Volume 3: Bony fishes part 2 (Opistognathidae to Molidae). Carpenter, K. E. Food and Agriculture Organization of the United Nations, Rome, 1426-1440.

Smith, G. C., and J. D. Parrish, 2002. Estuaries as Nurseries for the Jacks Caranx ignobilis and Caranx

Stevens P. W., D. A. Blewett and G. R. Poulakis, 2007. Variable habitat use by juvenile common snook, Centropomus undecimalis (Pisces: Centropomidae): applying a life-history model in a southwest Florida estuary. Bulletin of Marine Science 80: $93-108$.

Stevens, P. W., R. E. Boucek, A. A. Trotter, J. L. Ritch, E. R. Johnson, C. P. Shea, D. A. Blewett, and J. S. Rehage, 2018. Illustrating the value of cross-site comparisons : Habitat use by a large, euryhaline fish differs along a latitudinal gradient. Fisheries Research 208: 42-48. doi: 10.1016/j.fishres.2018.07.005. 
883

884

885

886

887

888

889

890

891

892

893

894

895

896

897

898

899

900

901

902

903

904

905

906

907

908

909

910

911

912

Stevens, P.W, Dutka-Gianelli, J., Nagid, E. J., Trotter, A. A., Johnson, K. G., Tuten, T., Whittington, J. A., 2020. Niche Partitioning Among Snook (Pisces: Centropomidae) in Rivers of Southeastern Florida and Implications for Species Range Limits. Estuaries and Coasts 43, 396-408. doi: 10.1007/s12237019-00650-x

Sudekum, A. E., J. D. Parrish, R. L. Radtke, and S. Ralston, 1991. Life history and ecology of large jacks in undisturbed, shallow, oceanic communities. Fishery Bulletin 89: 493-513.

Svanbäck, R. and P. Eklöv, 2002. Effects of habitat and food resources on morphology and ontogenetic growth trajectories in perch. Oecologia 131: 61 - 70. doi: 10.1007/s00442-001-0861-9

Syväranta, J., A. Lensu, T. J. Marjomäki, S. Oksanen, and R. I. Jones, 2013. An Empirical Evaluation of the Utility of Convex Hull and Standard Ellipse Areas for Assessing Population Niche Widths from Stable Isotope Data. PLoS ONE 8: 1-8. doi: 10.1371/journal.pone.0056094

Tirasin, E. M.; and T. Jorgensen, 1999. An evaluation of the precision of diet description. Marine Ecological-Progress Series.182: 243-252.

Usmar, N. R., 2012. Ontogenetic diet shifts in snapper (Pagrus auratus: Sparidae) within a New Zealand estuary. New Zealand Journal of Marine and Freshwater Research 46: 31-46. doi: $10.1080 / 00288330.2011 .587824$

Van Valen, L., 1965. Morphological Variation and Width of Ecological Niche. American Society of Naturalists 99: 377-390.

Vanderklift, M. A., and Ponsard, S., 2003. Sources of variation in consumer-diet $\delta^{15} \mathrm{~N}$ enrichment: a meta-analysis. Oecologia 136: 169-182. doi: 10.1007/s00442-003-1270-z

Vander Zanden, M. J., and J. B. Ramussen, 2001. Variation in $\delta^{15} \mathrm{~N}$ and $\delta^{13} \mathrm{C}$ trophic fractionation: Implications for aquatic food web studies. Limnology and Oceanography 46: 2061-2066.

Vasconcelos Filho, A. de L., S. Neumann-Leitão, E. Eskinazi-Leça, and A. M. E. Oliveira, 2010. Hábitos alimentares de peixes consumidores secundários do Canal de Santa Cruz, Pernambuco, Brasil. Tropical Oceanography Online 38: 121-128.

Vasconcelos Filho, A. de L., and A. M. E. Oliveira, 1999. Composição e ecologia da ictiofauna do Canal de Santa Cruz (Itamaracá - PE, Brasil). Trabalho oceanográfico UFPE 27: 101-113.

Vasconcelos Filho, A. L., S. Neumann-Leitão, E. Eskinazi-Leça, R. Schwamborn, A. M. E. Oliveira, and M. N. Paranaguá, 2003. Trophic interactions between fish and other compartment communities in a tropical estuary in Brazil as indicator of environmental quality. Transactions on Ecology and the 
914 Vasconcelos, R. P., S. Henriques, S. França, S. Pasquaud, I. Cardoso, M. Laborde, and H. N. Cabral, 915 2015. Global patterns and predictors of fish species richness in estuaries. Journal of Animal Ecology 916 84: 1331-1341. doi: 10.1111/1365-2656.12372.

917 Viana, A. P., F. Lucena-Frédou, F. Ménard, T. Frédou, V. Ferreira, A. S. Lira, and F. Le Loc'h, 2016. 918 Length-weight relations of 70 fish species from tropical coastal region of Pernambuco, Northeast 919 Brazil. Acta Ichthyologica et Piscatoria 46: 271-277. doi: 10.3750/AIP2016.46.3.12

920 Vilar, C. C., H. L. Spach, and J. C. Joyeux,2011. Spatial and temporal changes in the fish assemblage of a 921 subtropical estuary in Brazil: environmental effects. Journal of the Marine Biological Association of the United Kingdom 91: 635-648.

923 Yeung, C., and M. Yang, 2017. Habitat quality of the coastal southeastern Bering Sea for juvenile flat 924 fishes from the relationships between diet, body condition and prey availability. Journal of Sea Research Elsevier B.V. 119: 17-27. doi: 10.1016/j.seares.2016.10.002. 
929 Fig 1 Study area in northeastern Brazil, showing sampling locations within the Santa Cruz (a.), Suape (b.) and Sirinhaém (c.) estuaries (black dots). For each estuary, mangrove cover is indicated in dark grey.

931

932

933

934

935

936

937

938

939

940 Fig 4 Carbon $\left(\delta^{13} \mathrm{C}\right)$ and nitrogen $\left(\delta^{15} \mathrm{~N}\right)$ isotope ratios (mean \pm standard deviation) of Caranx latus and

941 C. hippos and the main available organic matter sources in three contrasted estuaries of northeastern

942 Brazil (Santa Cruz, Suape and Sirinhaém). Isotopic signatures for the organic matter sources sampled in

943 the estuaries and in adjacent coastal zones are represented by black and grey squares, respectively. Light

Fig 2 Number of individuals $(n)$ and length frequency distributions of the Caranx latus and C. hippos juveniles sampled in the estuaries of Santa Cruz, Suape and Sirinhaém.

Fig 3 Carbon $\left(\delta^{13} \mathrm{C}\right)$ and nitrogen $\left(\delta^{15} \mathrm{~N}\right)$ isotope ratios of the two jack species, Caranx latus and $C$. hippos, in three contrasted estuaries of northeastern Brazil (Santa Cruz, Suape and Sirinhaém). Ellipses represent the isotopic niche (SEAc) for both species. Pie charts present the global diet of each species based on prey relative weights $\left(W_{\mathrm{i}}\right.$, see Table 3$)$. grey polygons show the range of isotopic ratios of all estuarine organic matter sources except mangrove trees ( $R$. mangle). Arrows in the bottom left corner of each panel illustrate the average isotopic enrichment per trophic level $\left(+0.47 \pm 1.23 \%\right.$ for $\delta^{13} \mathrm{C}$ and $+2.54 \pm 0.11 \%$ for $\left.\delta^{15} \mathrm{~N}\right)$ usually applied in aquatic environments (Vander Zanden and Rasmussen, 2001; Vanderklift and Ponsard, 2003). Pie charts present the local diets of each species based on prey relative weights ( $W_{\mathrm{i}}$, see Supplementary Tables $\mathrm{S} 1$, S2 and S3). 
Characteristics

\begin{tabular}{|c|c|c|c|}
\hline & Santa Cruz & Suape & Sirinhaém \\
\hline Type & Ria & Coastal lagoon & Coastal plain \\
\hline Human pressures & $\begin{array}{l}\text { Aquaculture, agricultural, industrial } \\
\text { and domestic waste }\end{array}$ & $\begin{array}{l}\text { Industrial harbour, } \\
\text { industrial and } \\
\text { agriculture waste }\end{array}$ & $\begin{array}{l}\text { Industrial and domestic } \\
\text { waste }\end{array}$ \\
\hline Vegetated area $\left(\mathrm{km}^{2}\right)^{\dagger}$ & 48.0 & 23.1 & 17.0 \\
\hline Water surface area $\left(\mathrm{km}^{2}\right)^{\dagger}$ & 25.5 & 6.6 & 1.7 \\
\hline Mean depth (m) & 3.0 & 3.1 & 2.6 \\
\hline Max. depth (m) & 20 & 5 & 5 \\
\hline $\mathrm{N}$ of marine entrances & 2 & 1 & 1 \\
\hline $\begin{array}{l}\text { Width of marine entrances }(\mathrm{km} \text {, mean } \\
\text { and range })^{\dagger}\end{array}$ & $\begin{array}{c}0.9 \\
(0.5-1.3)\end{array}$ & 0.3 & 0.4 \\
\hline Pelagic productivity $\left(\mathrm{mgCm}^{-3} \mathrm{~h}^{-1}\right)$ & 14.7 & 2.0 & 34.2 \\
\hline Temperature $\left({ }^{\circ} \mathrm{C}\right.$, mean $\left.\pm \mathrm{SD}\right){ }^{\ddagger}$ & $28.5 \pm 1.1$ & $27.1 \pm 1.1$ & $27.2 \pm 2.4$ \\
\hline Salinity $($ mean $\pm \mathrm{SD}){ }^{\ddagger}$ & $31.1 \pm 2.9$ & $17.7 \pm 2.4$ & $9.5 \pm 3.6$ \\
\hline Pluviometry (mm, mean \pm SD) & $1517 \pm 122$ & $1869 \pm 367$ & $2053 \pm 699$ \\
\hline
\end{tabular}

Medeiros and Kjerfve, 1993; Medeiros et al., 2001; Neuman-Leitão et al., 2001; CPRH,

References 2003, 2003a; Borges, 2011; Silva, 2009; Guimarães et al., 2010; Silva et al., 2011; APAC, 2019; Gonzalez et al., 2019; Silva et al., 2019

Type, geomorphological classification on the type of estuary according to Pritchard's classification. Human pressure, existent anthropogenic activity with potential impact on the estuary. Vegetated area, area of mangrove cover vegetation. Max. depth, maximum depth during the high tide, usually near the estuary's entrance. $\mathrm{N}$ of marine entrances, number of connections to the sea. Pelagic productivity, mean annual phytoplankton productivity. Temperature, water surface temperature. Pluviometry, annual rainfall between 2014 and 2018.

957 Table 1 Summary of morphological characteristics, environmental settings and anthropogenic activities

958 of the three estuaries (Santa Cruz, Suape and Sirinhaém) along the coast of Pernambuco, northeastern 


\begin{tabular}{|c|c|c|c|c|c|c|c|}
\hline \multirow{2}{*}{ Estuary } & \multirow{2}{*}{ Species } & \multicolumn{2}{|c|}{ Stomach content analysis ${ }^{\dagger}$} & \multicolumn{4}{|c|}{ Stable isotopes analysis } \\
\hline & & $\mathrm{n}$ & SL (mm) & $\mathrm{n}$ & SL (mm) & $\delta^{13} \mathrm{C}(\%)$ & $\delta^{15} \mathrm{~N}(\%)$ \\
\hline \multirow[t]{2}{*}{ Santa Cruz } & C. latus & 70 & $\begin{array}{c}98 \pm 17 \\
{[50-135]}\end{array}$ & 30 & $\begin{array}{l}109 \pm 18 \\
{[80-138]}\end{array}$ & $\begin{array}{c}-18.85 \pm 1.59 \\
{[-23.4--16.5]}\end{array}$ & $\begin{array}{c}10.89 \pm 1.09 \\
{[8.6-13.0]}\end{array}$ \\
\hline & C. hippos & 70 & $\begin{array}{l}82 \pm 24 \\
{[36-131]}\end{array}$ & 30 & $\begin{array}{l}111 \pm 17 \\
{[82-142]}\end{array}$ & $\begin{array}{c}-18.94 \pm 1.66 \\
{[-22.3--16.3]}\end{array}$ & $\begin{array}{c}11.61 \pm 0.87 \\
{[10.4-13.7]}\end{array}$ \\
\hline \multirow[t]{2}{*}{ Suape } & C. latus & 67 & $\begin{array}{l}129 \pm 18 \\
{[82-157]}\end{array}$ & 15 & $\begin{array}{l}113 \pm 16 \\
{[86-141]}\end{array}$ & $\begin{array}{c}-18.65 \pm 1.45 \\
{[-21.9--16.6]}\end{array}$ & $\begin{array}{c}9.38 \pm 0.73 \\
{[8.0-10.2]}\end{array}$ \\
\hline & C. hippos & 20 & $\begin{array}{l}112 \pm 29 \\
{[49-156]}\end{array}$ & 10 & $\begin{array}{l}114 \pm 29 \\
{[65-145]}\end{array}$ & $\begin{array}{c}-20.25 \pm 2.77 \\
{[-23.6--15.7]}\end{array}$ & $\begin{array}{c}10.28 \pm 1.00 \\
{[8.8-12.0]}\end{array}$ \\
\hline \multirow[t]{2}{*}{ Sirinhaém } & C. latus & 70 & $\begin{array}{c}79 \pm 16 \\
{[35-116]}\end{array}$ & 15 & $\begin{array}{c}90 \pm 20 \\
{[70-124]}\end{array}$ & $\begin{array}{c}-20.07 \pm 1.08 \\
{[-24.4--15.9]}\end{array}$ & $\begin{array}{c}9.34 \pm 1.16 \\
{[8.2-11.6]}\end{array}$ \\
\hline & C. hippos & 39 & $\begin{array}{l}73 \pm 12 \\
{[47-98]}\end{array}$ & 12 & $\begin{array}{c}87 \pm 27 \\
{[65-138]}\end{array}$ & $\begin{array}{c}-19.64 \pm 2.39 \\
{[-23.6--16.1]}\end{array}$ & $\begin{array}{c}10.22 \pm 0.86 \\
{[8.7-11.7]}\end{array}$ \\
\hline
\end{tabular}

961

962 Table 2 Number of individuals (n), their mean standard length ( $\mathrm{SL} \pm$ S.D.) and isotopic ratio mean values

963 ( \pm S.D.) for carbon $\left(\delta^{13} \mathrm{C}\right)$ and nitrogen $\left(\delta^{15} \mathrm{~N}\right)$ of Caranx latus and C. hippos analysed for stomach

964 content and stable isotopes compositions, in the three estuaries (Santa Cruz, Suape and Sirinhaém).

965 Minimum and maximum values of each variable are between brackets. 


\begin{tabular}{|c|c|c|c|c|c|c|c|c|}
\hline \multirow{3}{*}{ Item } & \multicolumn{8}{|c|}{ Species } \\
\hline & \multicolumn{4}{|c|}{ Caranx latus $(n=207 ; 102 \pm 27 \mathrm{~mm})$} & \multicolumn{4}{|c|}{ Caranx hippos $(n=131 ; 84 \pm 25 \mathrm{~mm})$} \\
\hline & $F_{\mathrm{i}}(\%)$ & $N_{\mathrm{i}}(\%)$ & $W_{\mathrm{i}}(\%)$ & $Q$ & $F_{\mathrm{i}}(\%)$ & $N_{\mathrm{i}}(\%)$ & $W_{\mathrm{i}}(\%)$ & $Q$ \\
\hline ALGAE & $\begin{array}{c}12.08 \\
{[7.7-16.9]}\end{array}$ & $\begin{array}{c}4.19 \\
{[2.4-6.6]}\end{array}$ & $\begin{array}{c}0.29 \\
{[0.1-0.7]}\end{array}$ & 0.82 & $\begin{array}{c}2.90 \\
{[0.8-6.1]}\end{array}$ & $\begin{array}{c}0.86 \\
{[0.1-2.2]}\end{array}$ & $\begin{array}{c}0.18 \\
{[0-0.6]}\end{array}$ & 0.14 \\
\hline Chlorophyta (Unidentified) & $\begin{array}{c}0.97 \\
{[0-2.4]}\end{array}$ & $\begin{array}{c}0.40 \\
{[0-1.1]}\end{array}$ & $\begin{array}{c}0.01 \\
{[0-0.1]}\end{array}$ & 0.01 & - & - & - & - \\
\hline Unidentified Algae & $\begin{array}{c}11.11 \\
{[7.2-15.5]}\end{array}$ & $\begin{array}{c}4.87 \\
{[2.6-7.9]}\end{array}$ & $\begin{array}{c}0.28 \\
{[0.1-0.7]}\end{array}$ & 1.36 & $\begin{array}{c}3.05 \\
{[0.8-6.1]}\end{array}$ & $\begin{array}{c}1.00 \\
{[0.1-2.6]}\end{array}$ & $\begin{array}{c}0.18 \\
{[0-0.6]}\end{array}$ & 0.18 \\
\hline \multirow[t]{2}{*}{ FORAMINIFERA (Unidentified) } & $\begin{array}{c}0.48 \\
{[0-1.4]}\end{array}$ & $\begin{array}{c}0.08 \\
{[0-0.3]}\end{array}$ & $<0.01$ & 0.01 & - & - & - & - \\
\hline & $\begin{array}{c}0.48 \\
{[0-1.4]}\end{array}$ & $\begin{array}{c}0.10 \\
{[0-0.3]}\end{array}$ & $<0.01$ & 0.01 & & & & \\
\hline \multirow[t]{2}{*}{ NEMATODA (Unidentified) } & $\begin{array}{c}5.31 \\
{[2.4-8.7]}\end{array}$ & $\begin{array}{c}1.11 \\
{[0.5-1.8]}\end{array}$ & $<0.01$ & 0.01 & $\begin{array}{c}2.90 \\
{[0.8-61]}\end{array}$ & $\begin{array}{c}0.48 \\
{[0.1-1.1]}\end{array}$ & $<0.01$ & 0.01 \\
\hline & $\begin{array}{c}5.31 \\
{[2.4-8.7]}\end{array}$ & $\begin{array}{c}1.39 \\
{[0.6-2.3]}\end{array}$ & $<0.01$ & 0.01 & $\begin{array}{c}3.05 \\
{[0.8-6.1]}\end{array}$ & $\begin{array}{c}0.56 \\
{[0.1-1.3]}\end{array}$ & $<0.01$ & 0.01 \\
\hline \multirow[t]{2}{*}{ BIVALVIA (Unidentified) } & $\begin{array}{c}0.48 \\
{[0-1.4]}\end{array}$ & $\begin{array}{c}0.32 \\
{[0-1.0]}\end{array}$ & $<0.01$ & 0.01 & $\begin{array}{c}0.72 \\
{[0-2.3]}\end{array}$ & $\begin{array}{c}0.10 \\
{[0-0.4]}\end{array}$ & $<0.01$ & 0.01 \\
\hline & $\begin{array}{c}0.48 \\
{[0-1.4]}\end{array}$ & $\begin{array}{c}0.40 \\
{[0-1.3]}\end{array}$ & $<0.01$ & 0.01 & $\begin{array}{c}0.76 \\
{[0-2.3]}\end{array}$ & $\begin{array}{c}0.11 \\
{[0-0.4]}\end{array}$ & $<0.01]$ & 0.01 \\
\hline \multirow[t]{2}{*}{ GASTROPODA (Unidentified) } & $\begin{array}{c}2.90 \\
{[1.0-5.3]}\end{array}$ & $\begin{array}{c}1.26 \\
{[0.3-2.6]}\end{array}$ & $\begin{array}{c}0.01 \\
{[0-0.1]}\end{array}$ & 0.01 & - & - & - & - \\
\hline & $\begin{array}{c}2.90 \\
{[1.0-5.3]}\end{array}$ & $\begin{array}{c}1.59 \\
{[0.3-3.3]}\end{array}$ & $\begin{array}{c}0.01 \\
{[0-0.1]}\end{array}$ & 0.01 & & & & \\
\hline
\end{tabular}

Table 3 Frequency of occurrence $\left(F_{\mathrm{i}}\right)$, relative abundance $\left(N_{\mathrm{i}}\right)$ and weight $\left(W_{\mathrm{i}}\right)$ and alimentary coefficient $(Q)$ of prey items of Caranx latus and Caranx hippos in northeastern Brazil estuaries. Dietary indexes estimate for major taxonomic groups are shown in bold. Confidence interval estimates (95\%) for dietary indexes are displayed between square brackets. The number of fish specimens $(n)$ and their mean standard length $(\mathrm{SL}, \pm \mathrm{SD})$ are presented for each species. 


\begin{tabular}{|c|c|c|c|c|c|c|c|c|c|c|c|}
\hline \multicolumn{4}{|c|}{ POLYCHAETA (Unidentified) } & $\begin{array}{c}0.48 \\
{[0-1.4]}\end{array}$ & $\begin{array}{c}0.08 \\
{[0-0.3]}\end{array}$ & $<0.01$ & 0.01 & $\begin{array}{c}1.45 \\
{[0-3.8]}\end{array}$ & $\begin{array}{c}0.57 \\
{[0-1.7]}\end{array}$ & $\begin{array}{c}0.01 \\
{[0-0.1]}\end{array}$ & 0.01 \\
\hline & & & & $\begin{array}{c}0.48 \\
{[0-1.4]}\end{array}$ & $\begin{array}{c}0.10 \\
{[0-0.3]}\end{array}$ & $<0.01$ & 0.01 & $\begin{array}{c}1.53 \\
{[0-3.8]}\end{array}$ & $\begin{array}{c}0.67 \\
{[0-1.9]}\end{array}$ & $\begin{array}{c}0.01 \\
{[0-0.1]}\end{array}$ & 0.01 \\
\hline \multirow{2}{*}{\multicolumn{4}{|c|}{ OLIGOCHAETA (Unidentified) }} & $\begin{array}{c}0.48 \\
{[0-1.4]}\end{array}$ & $\begin{array}{c}0.08 \\
{[0-0.3]}\end{array}$ & $<0.01$ & 0.01 & $\begin{array}{c}2.17 \\
{[0-17.1]}\end{array}$ & $\begin{array}{c}0.29 \\
{[0-0.7]}\end{array}$ & $<0.01$ & 0.01 \\
\hline & & & & $\begin{array}{c}0.48 \\
{[0-1.4]}\end{array}$ & $\begin{array}{c}0.10 \\
{[0-0.3]}\end{array}$ & $<0.01$ & 0.01 & $\begin{array}{c}2.29 \\
{[0-5.3]}\end{array}$ & $\begin{array}{c}0.33 \\
{[0-0.9]}\end{array}$ & $<0.01$ & 0.01 \\
\hline \multicolumn{4}{|l|}{ CRUSTACEA } & $\begin{array}{c}49.28 \\
{[42.5-56.0]}\end{array}$ & $\begin{array}{c}26.07 \\
{[19.7-33.3]}\end{array}$ & $\begin{array}{c}23.30 \\
{[14.2-34.6]}\end{array}$ & 705.34 & $\begin{array}{c}60.87 \\
{[51.9-68.7]}\end{array}$ & $\begin{array}{c}65.97 \\
{[51.7-75.4]}\end{array}$ & $\begin{array}{c}38.22 \\
{[22.8-60.3]}\end{array}$ & 2537.20 \\
\hline \multicolumn{4}{|c|}{ Cirripedia (Unidentified) } & $\begin{array}{c}0.48 \\
{[0-1.4]}\end{array}$ & $\begin{array}{c}0.60 \\
{[0-2.0]}\end{array}$ & $<0.01$ & 0.01 & $\begin{array}{c}0.76 \\
{[0-2.3]}\end{array}$ & $\begin{array}{c}0.78 \\
{[0-2.9]}\end{array}$ & $<0.01$ & 0.01 \\
\hline \multicolumn{4}{|c|}{ Copepoda (Unidentified) } & $\begin{array}{c}1.45 \\
{[0-3.4]}\end{array}$ & $\begin{array}{c}1.79 \\
{[0-4.6]}\end{array}$ & $<0.01$ & 0.01 & $\begin{array}{c}7.63 \\
{[3.1-12.2]}\end{array}$ & $\begin{array}{c}2.12 \\
{[0.8-2.1]}\end{array}$ & $<0.01$ & 0.01 \\
\hline \multirow[t]{9}{*}{ Malacostraca } & Decapoda & Brachyura & Portunidae & $\begin{array}{c}0.48 \\
{[0-1.4]}\end{array}$ & $\begin{array}{c}0.10 \\
{[0-0.3]}\end{array}$ & $\begin{array}{c}0.10 \\
{[0-0.4]}\end{array}$ & 0.01 & $\begin{array}{c}1.53 \\
{[0-3.8]}\end{array}$ & $\begin{array}{c}0.22 \\
{[0-0.6]}\end{array}$ & $\begin{array}{c}0.05 \\
{[0-0.2]}\end{array}$ & 0.01 \\
\hline & & & Sesarmidae & $\begin{array}{c}0.48 \\
{[0-1.4]}\end{array}$ & $\begin{array}{c}0.10 \\
{[0-0.3]}\end{array}$ & $\begin{array}{c}0.05 \\
{[0-0.2]}\end{array}$ & 0.01 & - & - & - & - \\
\hline & & & Unidentified Brachyura & $\begin{array}{c}0.97 \\
{[0-2.4]}\end{array}$ & $\begin{array}{c}0.70 \\
{[0-2.1]}\end{array}$ & $\begin{array}{c}0.14 \\
{[0-0.5]}\end{array}$ & 0.09 & $\begin{array}{c}1.53 \\
{[0-3.8]}\end{array}$ & $\begin{array}{c}0.33 \\
{[0-1.0]}\end{array}$ & $\begin{array}{c}0.32 \\
{[0-1.2]}\end{array}$ & 0.10 \\
\hline & & Caridea & Alpheidae & $\begin{array}{c}4.83 \\
{[1.9-8.2]}\end{array}$ & $\begin{array}{c}1.99 \\
{[0.7-3.9]}\end{array}$ & $\begin{array}{c}1.56 \\
{[0.1-4.7]}\end{array}$ & 3.10 & $\begin{array}{c}1.53 \\
{[0-3.8]}\end{array}$ & $\begin{array}{c}0.22 \\
{[0-0.6]}\end{array}$ & $\begin{array}{c}1.22 \\
{[0-4.8]}\end{array}$ & 0.26 \\
\hline & & & Unidentified Caridea & $\begin{array}{c}2.90 \\
{[1.0-5.3]}\end{array}$ & $\begin{array}{c}0.99 \\
{[0.7-2.0]}\end{array}$ & $\begin{array}{c}1.38 \\
{[0.3-2.9]}\end{array}$ & 1.36 & - & - & - & - \\
\hline & & Dendrobranchiata & Aristeidae & $\begin{array}{c}0.48 \\
{[0-1.4]}\end{array}$ & $\begin{array}{c}0.20 \\
{[0-0.7]}\end{array}$ & $\begin{array}{c}0.06 \\
{[0-0.2]}\end{array}$ & 0.01 & - & - & - & - \\
\hline & & & Penaeidae & $\begin{array}{c}11.59 \\
{[7.2-15.9]}\end{array}$ & $\begin{array}{c}4.87 \\
{[2.6-7.7]}\end{array}$ & $\begin{array}{c}14.60 \\
{[7.8-23.5]}\end{array}$ & 71.10 & $\begin{array}{c}20.61 \\
{[13.7-27.5]}\end{array}$ & $\begin{array}{c}8.37 \\
{[3.8-15.4]}\end{array}$ & $\begin{array}{c}19.26 \\
{[9.9-33.3]}\end{array}$ & 161.20 \\
\hline & & \multicolumn{2}{|c|}{ Unidentified Decapoda } & $\begin{array}{c}15.46 \\
{[10.6-20.3]}\end{array}$ & $\begin{array}{c}8.84 \\
{[4.6-15.0]}\end{array}$ & $\begin{array}{c}4.86 \\
{[2.2-8.6]}\end{array}$ & 42.96 & $\begin{array}{c}23.66 \\
{[16.8-31.3]}\end{array}$ & $\begin{array}{c}15.07 \\
{[7.9-15.4]}\end{array}$ & $\begin{array}{c}10.56 \\
{[4.0-22.2]}\end{array}$ & 159.13 \\
\hline & \multicolumn{3}{|c|}{ Isopoda (Unidentified) } & $\begin{array}{c}2.90 \\
{[1.0-5.3]}\end{array}$ & $\begin{array}{c}0.79 \\
{[0.2-1.6]}\end{array}$ & $\begin{array}{c}0.01 \\
{[0-0.1]}\end{array}$ & 0.01 & $\begin{array}{c}3.82 \\
{[0.8-7.6]}\end{array}$ & $\begin{array}{c}0.56 \\
{[0.1-1.2]}\end{array}$ & $\begin{array}{c}0.06 \\
{[0-0.2]}\end{array}$ & 0.03 \\
\hline
\end{tabular}

Table 3 Continued. 


\begin{tabular}{|c|c|c|c|c|c|c|c|c|c|c|}
\hline & \multicolumn{2}{|l|}{ Mysida (Unidentified) } & $\begin{array}{c}1.93 \\
{[0.5-3.9]}\end{array}$ & $\begin{array}{c}0.79 \\
{[0.1-1.7]}\end{array}$ & $\begin{array}{c}0.01 \\
{[0-0.1]}\end{array}$ & 0.01 & $\begin{array}{c}7.63 \\
{[3.1-12.2]}\end{array}$ & $\begin{array}{c}36.61 \\
{[12.7-53.9]}\end{array}$ & $\begin{array}{c}4.67 \\
{[0.9-11.1]}\end{array}$ & 170.96 \\
\hline & \multicolumn{2}{|l|}{ Stomatopoda (Unidentified) } & - & - & - & - & $\begin{array}{c}0.76 \\
{[0-2.3]}\end{array}$ & $\begin{array}{c}0.11 \\
{[0-0.4]}\end{array}$ & $\begin{array}{c}0.03 \\
{[0-0.1]}\end{array}$ & 0.01 \\
\hline \multicolumn{3}{|c|}{ Ostracoda (Unidentified) } & $\begin{array}{c}4.35 \\
{[1.9-7.2]}\end{array}$ & $\begin{array}{c}2.78 \\
{[0.8-5.6]}\end{array}$ & $<0.01$ & 0.01 & $\begin{array}{c}1.53 \\
{[0-3.8]}\end{array}$ & $\begin{array}{c}0.56 \\
{[0-1.5]}\end{array}$ & $<0.01$ & 0.1 \\
\hline \multicolumn{3}{|c|}{ Unidentified Crustacea } & $\begin{array}{c}14.98 \\
{[10.1-19.8]}\end{array}$ & $\begin{array}{c}8.34 \\
{[4.5-13.2]}\end{array}$ & $\begin{array}{c}0.90 \\
{[0.4-1.7]}\end{array}$ & 7.50 & $\begin{array}{c}9.92 \\
{[5.3-15.3]}\end{array}$ & $\begin{array}{c}9.49 \\
{[2.9-17.9]}\end{array}$ & $\begin{array}{c}2.61 \\
{[0.2-6.9]}\end{array}$ & 24.76 \\
\hline \multicolumn{3}{|l|}{ HEXAPODA } & $\begin{array}{c}0.48 \\
{[0-1.4]}\end{array}$ & $\begin{array}{c}0.08 \\
{[0-0.3]}\end{array}$ & $<0.01$ & 0.01 & - & - & - & - \\
\hline \multicolumn{3}{|c|}{ Unidentified Insecta } & $\begin{array}{c}0.48 \\
{[0-1.4]}\end{array}$ & $\begin{array}{c}0.10 \\
{[0-0.3]}\end{array}$ & $<0.01$ & 0.01 & & & & \\
\hline \multicolumn{3}{|c|}{ VERTEBRATA } & $\begin{array}{c}84.06 \\
{[78.8-88.9]}\end{array}$ & $\begin{array}{c}46.29 \\
{[37.7-54.9]}\end{array}$ & $\begin{array}{c}75.10 \\
{[63.5-84.4]}\end{array}$ & 3252.60 & $\begin{array}{c}71.74 \\
{[64.1-79.4]}\end{array}$ & $\begin{array}{c}20.17 \\
{[13.8-29.1]}\end{array}$ & $\begin{array}{c}60.13 \\
{[37.9-76.0]}\end{array}$ & 1205.15 \\
\hline Thaliacea & Salpida & Salpidae & $\begin{array}{c}0.97 \\
{[0-2.4]}\end{array}$ & $\begin{array}{c}0.20 \\
{[0-0.5]}\end{array}$ & $\begin{array}{c}0.09 \\
{[0-0.3]}\end{array}$ & 0.01 & - & - & - & - \\
\hline \multirow[t]{7}{*}{ Teleostei } & \multirow[t]{2}{*}{ Clupeiformes } & Clupeidae & $\begin{array}{c}1.93 \\
{[0.5-3.9]}\end{array}$ & $\begin{array}{c}0.70 \\
{[0.1-1.6]}\end{array}$ & $\begin{array}{c}2.61 \\
{[0-6.8]}\end{array}$ & 1.82 & $\begin{array}{c}2.29 \\
{[0-5.3]}\end{array}$ & $\begin{array}{c}0.89 \\
{[0-2.5]}\end{array}$ & $\begin{array}{c}7.18 \\
{[0-19.5]}\end{array}$ & 6.39 \\
\hline & & Engraulidae & $\begin{array}{c}4.35 \\
{[1.9-7.2]}\end{array}$ & $\begin{array}{c}1.59 \\
{[0.5-3.1]}\end{array}$ & $\begin{array}{c}2.46 \\
{[0.4-5.7]}\end{array}$ & 3.91 & $\begin{array}{c}3.05 \\
{[0.8-6.1]}\end{array}$ & $\begin{array}{c}0.45 \\
{[0.1-1.0]}\end{array}$ & $\begin{array}{c}4.43 \\
{[0.6-9.9]}\end{array}$ & 1.99 \\
\hline & \multirow[t]{2}{*}{ Gobiiformes } & Eleotridae & $\begin{array}{c}1.45 \\
{[0-3.4]}\end{array}$ & $\begin{array}{c}0.30 \\
{[0-0.7]}\end{array}$ & $\begin{array}{c}0.44 \\
{[0-1.1]}\end{array}$ & 0.13 & $\begin{array}{c}0.76 \\
{[0-2.3]}\end{array}$ & $\begin{array}{c}0.11 \\
{[0-0.4]}\end{array}$ & $\begin{array}{c}0.90 \\
{[0-3.4]}\end{array}$ & 0.09 \\
\hline & & Gobiidae & $\begin{array}{c}23.67 \\
{[17.9-29.9]}\end{array}$ & $\begin{array}{c}7.55 \\
{[5.3-10.4]}\end{array}$ & $\begin{array}{c}39.99 \\
{[19.7-57.6]}\end{array}$ & 301.92 & $\begin{array}{c}19.08 \\
{[12.2-26.0]}\end{array}$ & $\begin{array}{c}4.35 \\
{[2.4-7.3]}\end{array}$ & $\begin{array}{c}33.28 \\
{[7.4-57.7]}\end{array}$ & 144.76 \\
\hline & \multirow[t]{3}{*}{ Perciformes } & Carangidae & $\begin{array}{c}0.48 \\
{[0-1.4]}\end{array}$ & $\begin{array}{c}0.10 \\
{[0-0.3]}\end{array}$ & $\begin{array}{c}0.16 \\
{[0-0.6]}\end{array}$ & 0.01 & $\begin{array}{c}2.29 \\
{[0-5.3]}\end{array}$ & $\begin{array}{c}2.01 \\
{[0-5.9]}\end{array}$ & $\begin{array}{c}0.74 \\
{[0-2.6]}\end{array}$ & 1.48 \\
\hline & & Gerreidae & $\begin{array}{c}9.66 \\
{[5.8-14.0]}\end{array}$ & $\begin{array}{c}4.37 \\
{[2.0-7.8]}\end{array}$ & $\begin{array}{c}2.73 \\
{[0.6-6.0]}\end{array}$ & 11.93 & $\begin{array}{c}0.76 \\
{[0-2.3]}\end{array}$ & $\begin{array}{c}0.11 \\
{[0-0.4]}\end{array}$ & $\begin{array}{c}0.08 \\
{[0-0.3]}\end{array}$ & 0.01 \\
\hline & & Scianidae & $\begin{array}{c}0.48 \\
{[0-1.4]}\end{array}$ & $\begin{array}{c}0.10 \\
{[0-0.3]}\end{array}$ & $\begin{array}{c}0.24 \\
{[0-0.9]}\end{array}$ & 0.02 & - & - & - & - \\
\hline
\end{tabular}

Table 3 Continued. 


\begin{tabular}{|c|c|c|c|c|c|c|c|c|c|}
\hline Pleuronectiformes & Cynoglossidae & $\begin{array}{c}0.48 \\
{[0-1.4]}\end{array}$ & $\begin{array}{c}0.10 \\
{[0-0.3]}\end{array}$ & $\begin{array}{c}0.14 \\
{[0-0.5]}\end{array}$ & 0.01 & - & - & - & - \\
\hline \multirow[b]{2}{*}{ Unidentified teleostei } & Paralichthyidae & $\begin{array}{c}0.48 \\
{[0-1.4]}\end{array}$ & $\begin{array}{c}0.10 \\
{[0-0.3]}\end{array}$ & $\begin{array}{c}0.04 \\
{[0-0.2]}\end{array}$ & 0.01 & - & - & - & - \\
\hline & & $\begin{array}{c}60.39 \\
{[53.6-67.1]}\end{array}$ & $\begin{array}{c}43.00 \\
{[32.2-53.6]}\end{array}$ & $\begin{array}{c}27.12 \\
{[18.2-39.0]}\end{array}$ & 1166.18 & $\begin{array}{c}54.20 \\
{[45.8-62.6]}\end{array}$ & $\begin{array}{c}14.96 \\
{[9.4-23.5]}\end{array}$ & $\begin{array}{c}14.40 \\
{[8.4-24.0]}\end{array}$ & 215.2 \\
\hline DEBRIS & & $\begin{array}{c}29.47 \\
{[23.7-35.7]}\end{array}$ & $\begin{array}{c}20.46 \\
{[14.9-26.2]}\end{array}$ & $\begin{array}{c}1.30 \\
{[0.3-3.2]}\end{array}$ & - & $\begin{array}{c}33.59 \\
{[26.0-42.0]}\end{array}$ & $\begin{array}{c}11.64 \\
{[7.2-18.3]}\end{array}$ & $\begin{array}{c}1.46 \\
{[0.4-3.1]}\end{array}$ & - \\
\hline Plastic debris & & $\begin{array}{c}19.81 \\
{[14.5-25.6]}\end{array}$ & $\begin{array}{c}13.90 \\
{[9.3-18.8]}\end{array}$ & $<0.01$ & - & $\begin{array}{c}18.12 \\
{[12.2-25.2]}\end{array}$ & $\begin{array}{c}6.50 \\
{[3.5-10.8]}\end{array}$ & $<0.01$ & - \\
\hline Unidentified organic matter and sediment debris & & $\begin{array}{c}14.98 \\
{[10.1-19.8]}\end{array}$ & $\begin{array}{c}6.56 \\
{[3.5-10.2]}\end{array}$ & $\begin{array}{c}1.30 \\
{[0.3-3.2]}\end{array}$ & - & $\begin{array}{c}18.84 \\
{[12.2-26.0]}\end{array}$ & $\begin{array}{c}5.07 \\
{[2.7-8.8]}\end{array}$ & $\begin{array}{c}1.45 \\
{[0.4-3.1]}\end{array}$ & - \\
\hline
\end{tabular}

Table 3 Continued. 


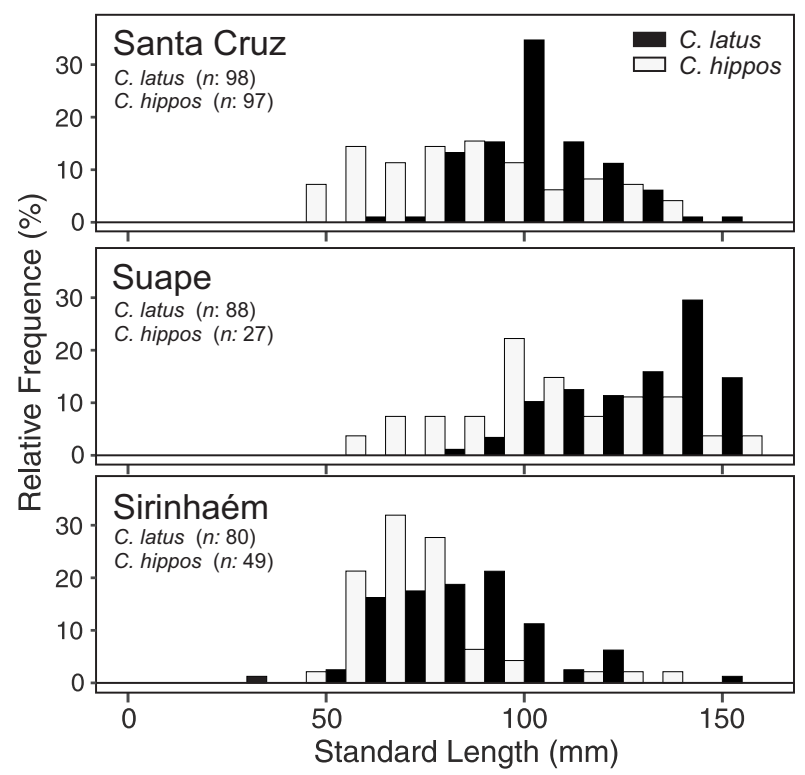




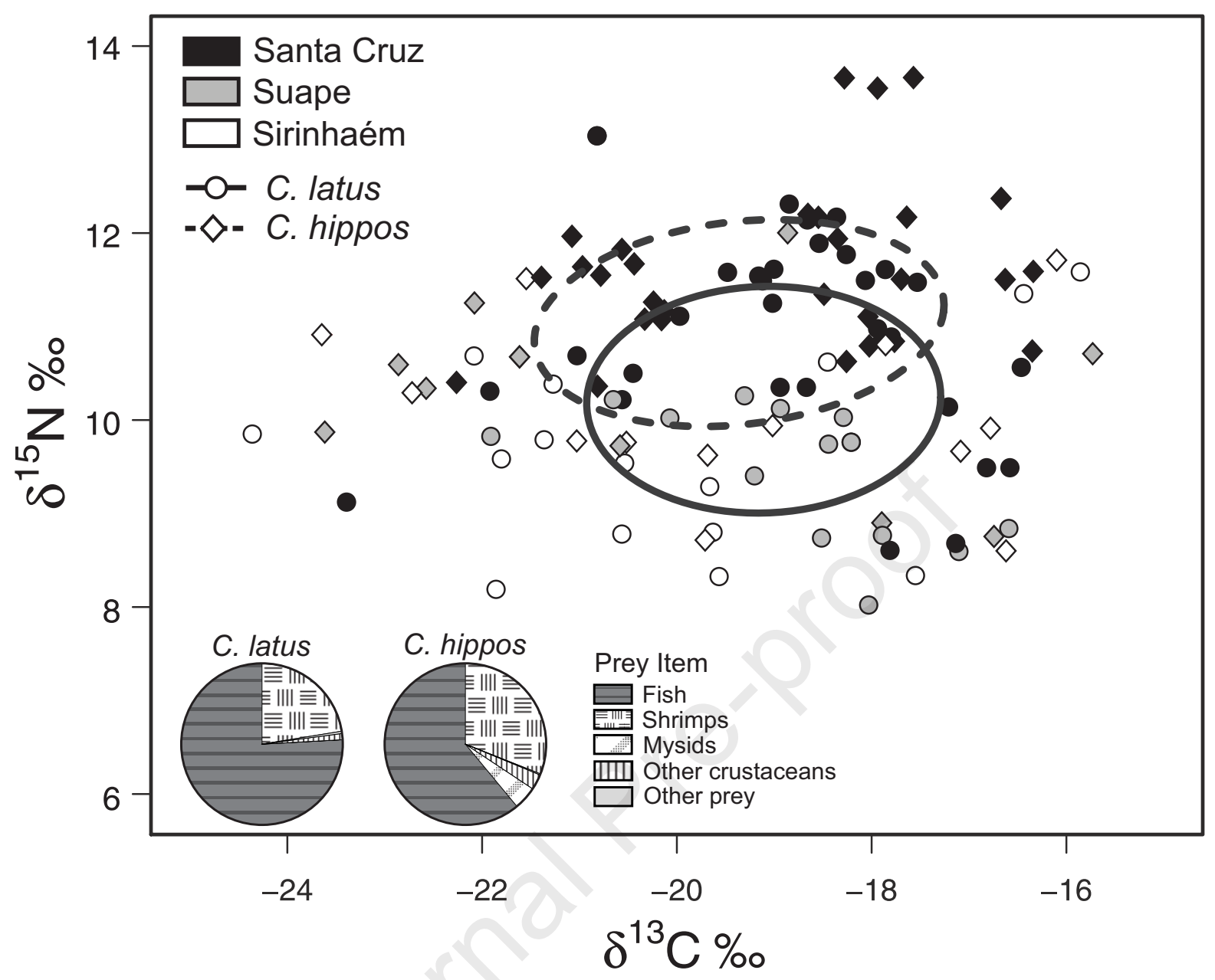



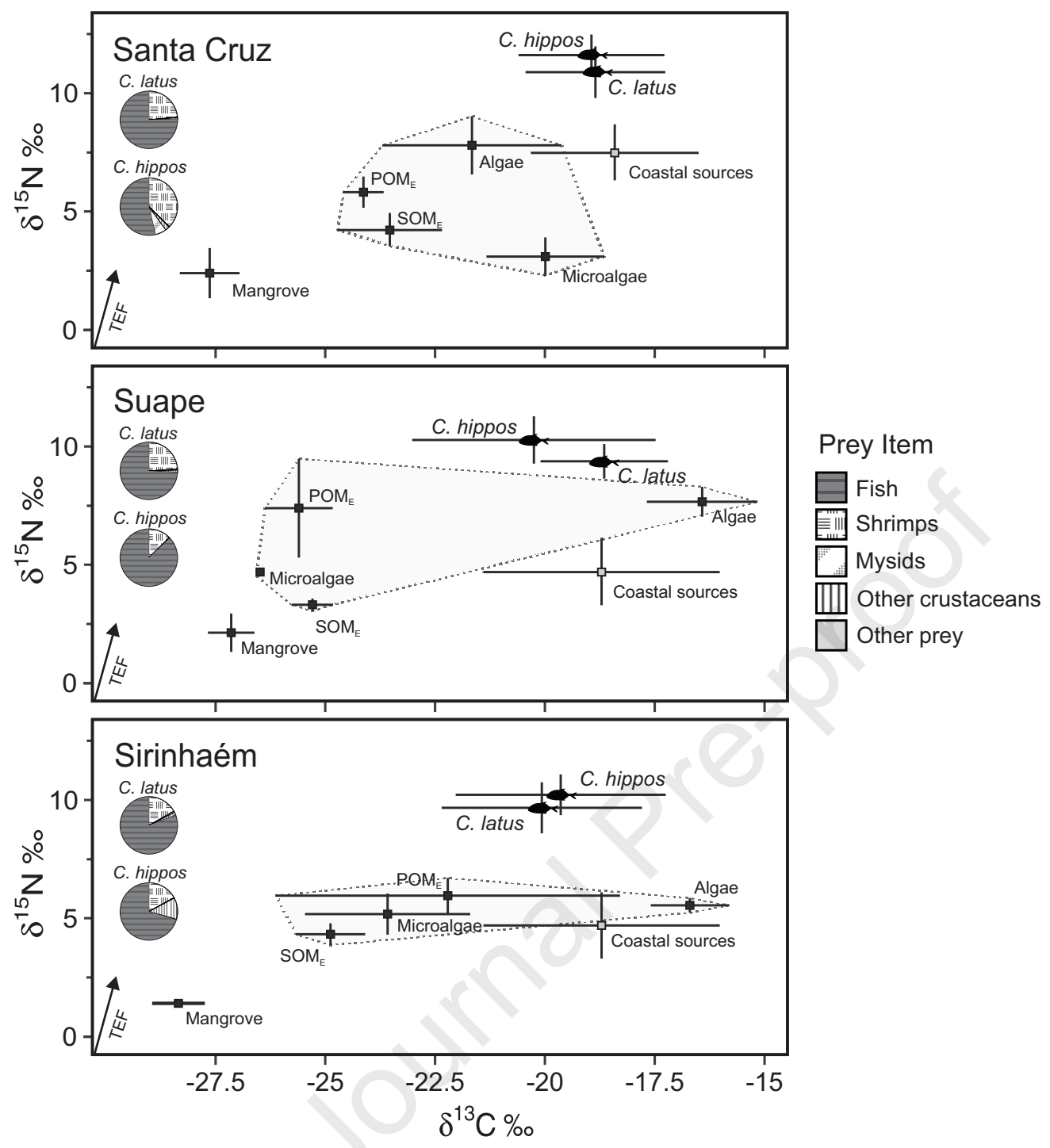


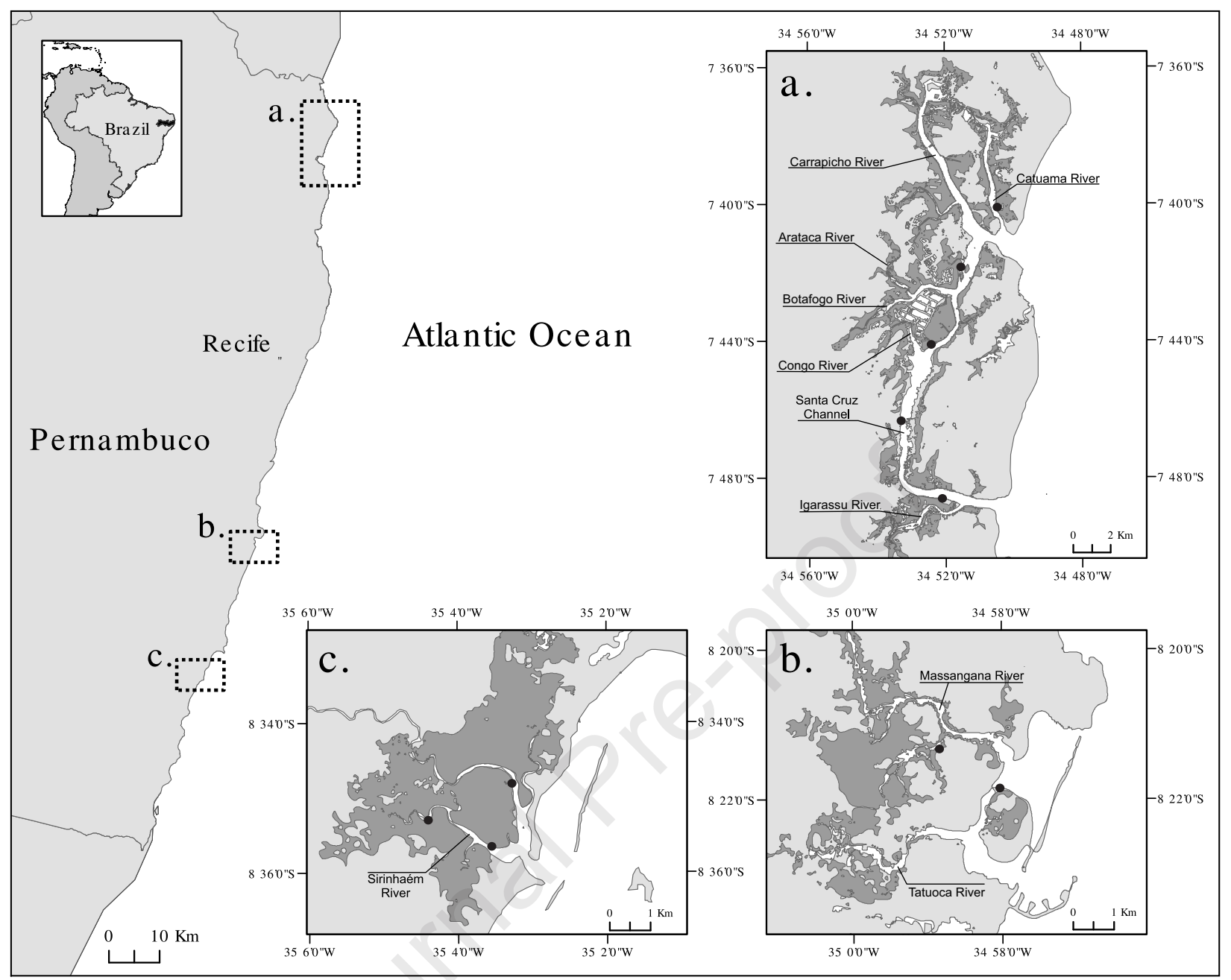




\section{Highlights}

- The trophic ecology of two jack species was described for three tropical estuaries

- Both species mostly eat fish and crustaceans during their estuarine juvenile life

- Their overall isotopic niches are very similar and the overlap between them is $>68 \%$

- However, spatial changes in diet allow to reduce this latter to $27-57 \%$

- Food partitioning strategies between the two species differ among estuaries 
Júlio Guazzelli Gonzalez

Universidade Federal Rural de Pernambuco

Departamento de Pesca e Aquicultura

52171-900, Recife, Pernambuco, Brazil

julio.guazzelli-gonzalez@etu.umontpellier.fr

March 12, 2021

All co-authors have materially participated in the manuscript preparation (see below for more details) and all approved the present version of the manuscript.

Júlio Guazzelli Gonzalez: Sampling procedures, laboratorial analysis, data analysis and manuscript preparation.

Audrey M. Darnaude: Data analysis and manuscript preparation.

Paulo José Duarte-Neto: Data analysis and manuscript preparation.

François Le Loc'h: Data analysis and manuscript preparation.

Mayara Constantino de Lima: Sampling and laboratory analyses.

Frédéric Ménard: Data analysis and manuscript preparation.

Valdimere Ferreira: Sampling and laboratory analyses.

Flávia Lucena Frédou: Data analysis and manuscript preparation.

Jean-Marie Munaron: laboratory analyses.

Thierry Frédou: Sampling, data analysis and manuscript preparation.

Sincerely.

Júlio Guazzelli Gonzalez (on behalf of the authors)

Universidade Federal Rural de Pernambuco 


\section{Declaration of interests}

XThe authors declare that they have no known competing financial interests or personal relationships that could have appeared to influence the work reported in this paper.

$\square$ The authors declare the following financial interests/personal relationships which may be considered as potential competing interests: 